$$
\begin{gathered}
\text { UNIVERSITY OF CALIFORNIA } \\
\text { COLLEGE OF AGRICULTURE } \\
\text { AGRICULTURAL EXPERIMENT STATION }
\end{gathered}
$$

BERKELEY, CALIFORNIA

\title{
THE EFFECTS OF DESICCATING WINDS ON CITRUS TREES
}

H. S. REED and E. T. BARTHOLOMEW

\section{BULLETIN 484}

JANUARY, 1930 
Digitized by the Internet Archive in 2012 with funding from University of California, Davis Libraries 


\title{
THE EFFECTS OF DESICCATING WINDS ON CITRUS TREES ${ }^{1,2}$
}

\author{
H. S. REED 3 AND E. T. BARTHOLOMEW4
}

\section{INTRODUCTION}

Citrus groves in southern California are often seriously injured by hot, dry winds from the interior deserts during October, November, and December. The local name for these winds is 'northers.' They often blow continuously for several days, but at times intermittently. They carry more or less dust, depending upon the character of the country over which they blow. Citrus trees in exposed situations are severely damaged by these winds, but no locality is entirely exempt from injury.

Wind of this character occurs in many parts of the world and is designated by various terms. It was first noted and studied in Switzerland where it was called 'foehn.' It has other interesting local names, e.g., sukhovey (southern Russia), sirocco (Palestine and northern Africa), levanto (Canary Islands), chinook (northwestern United States), foehn (Japan and Formosa), Santa Ana (southern California).

The importance of the problem was brought out by the survey of orchard practices made by Vaile (1924). ${ }^{5}$ At the request of certain organizations of citrus growers work was started on the problem with a view to mitigating, to some extent, the injuries from desiccating winds. The horiticultural importance of the problem became clear as the work proceeded. Certain means, which seem to be practicable, of alleviating injuries to the trees have been found. Some ecological and physiological data have also been obtained, which have been summarized and incorporated in the publication because they call attention to certain conditions of the habitat of citrus which have not been extensively studied.

1 Paper No. 210, University of California Graduate School of Tropical Agriculture and Citrus Experiment Station, Riverside, California.

2 Certain sections, indicated in the text, have been contributed by H. E. Wahlberg and Woodbridge Metcalf.

3 Professor of Plant Physiology in the Citrus Experiment Station and Graduate School of Tropical Agriculture and Plant Physiologist in the Experiment Station.

4 Associate Plant Physiologist in the Citrus Experiment Station.

5 See "Literature Cited," pages 58 and 59, for complete data on citations, which are referred to in the text by author and date of publication. 
The maintenance of the water equilibrium in the soil-plant-atmosphere system in an arid habitat is a serious problem for any plant, but especially so for a broad-leaved evergreen like the citrus tree. The apple, peach, walnut, and other introduced fruit trees escape severe desiccation after the season of active growth by shedding their leaves, although they may lose enough water through the thin bark of the twigs to cause injury. The survival of the citrus tree in an arid situation may depend upon $(a)$ the ability of the tree to conserve water, and $(b)$ the skill of the horticulturist in supplying the necessary moisture, or in providing barriers against the winds.

The damage produced by desiccating winds varies with different species and even varieties of citrus trees. Orange trees, for example, are more severely damaged by descciating winds than other species of Citrus grown in California, though the grapefruit (pomelo) is nearly as susceptible (Reed, 1920).

The injury is shown not only by fruit and foliage, but even by the twigs, on the windward side of the tree. The crop of Valencia oranges, which is the variety principally grown in some of the exposed districts, is severely damaged every few years by northers. Figure 1 shows a Valencia orange tree several weeks after a norther which had defoliated many of the branches and blown much fruit from the top and windward side of the tree. Navel orange trees suffer similar injury to the foliage and twigs, but their fruits are even more severely damaged because they are more nearly mature than Valencias during the period of desiccating winds.

The tender young growth on grapefruit trees in the Imperial Valley is sometimes killed by dry, hot winds in the spring months except where protected by windbreaks. The fruits also are abraded by repeated impacts with the branches during wind storms. The fruitbearing twigs are twisted as the fruits sway back and forth in the wind and many are broken, allowing the fruit to drop.

Lemon trees lose their foliage but not to such an extent as orange trees. Soon after the norther begins to blow, the trees lose many of their leaves; consequently the evaporation of water from the tree is not excessive. The leaves separate at the abscission layer between petiole and blade. The fruits are damaged by striking branches and thorns. The results of these injuries are given in a subsequent paragraph.

The foliage of tangerine trees is not greatly injured by desceiating wind, but the ripening fruit may be blown off by the winds of late winter. 


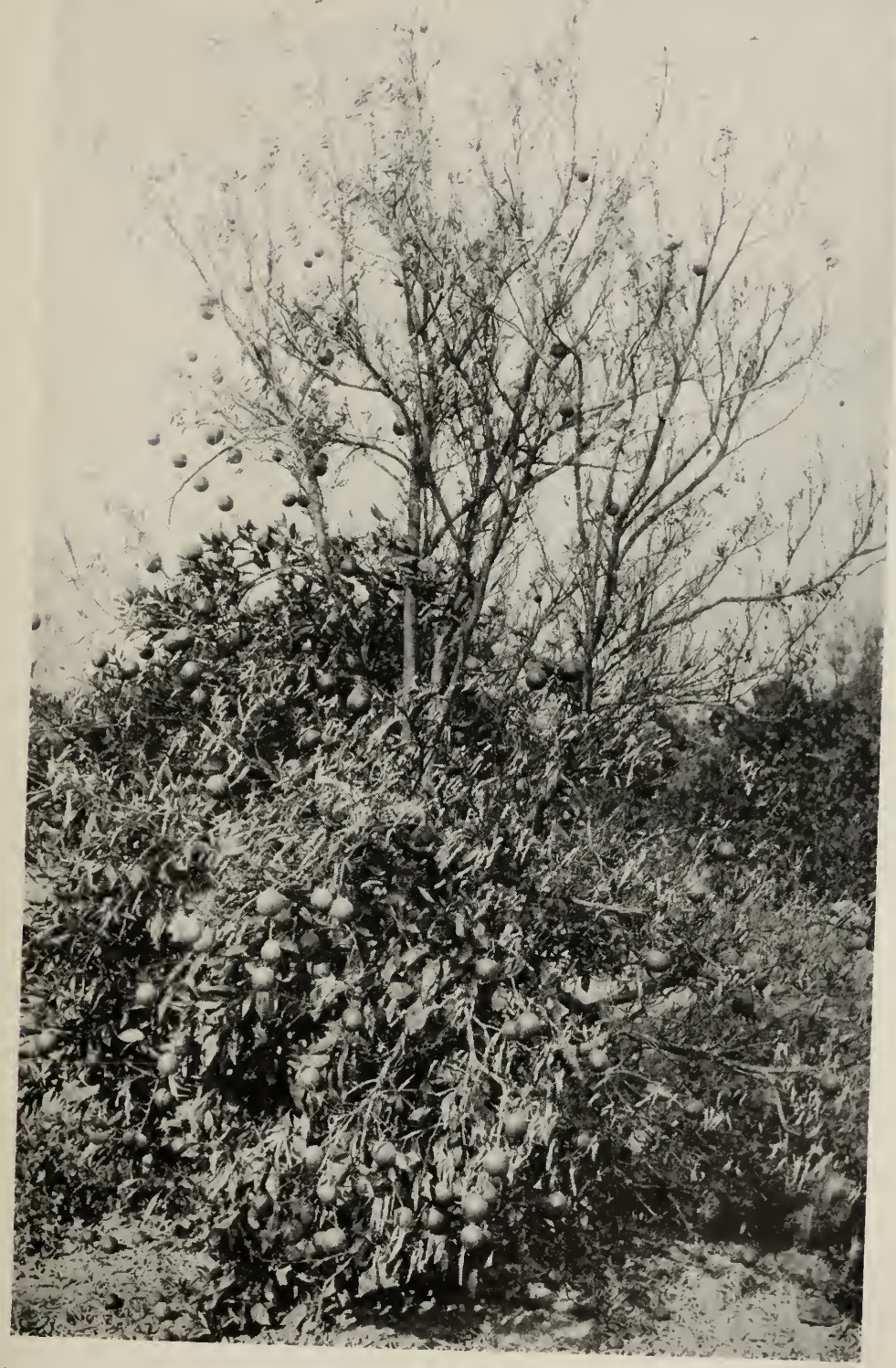

Fig. 1.-Effect of a norther which defoliated the top and windward side of a Valencia orange tree. The windburned leaves fell before the photograph was taken, foreground. little remained on the loew upper branches although a 
The effects of desiccating winds on fruit trees have been studied hitherto by relatively few investigators.

Citrus trees in North Africa are injured by desiccating winds, very much as in California. Boeuf and Genet (1906) reported that damage was caused by hot, dry winds from the inland deserts and that orange trees suffered more severely than other cultivated species of Citrus. The orange leaves were dried to a crisp without losing their green color, but the twigs turned brown, especially after the dead leaves fell off. Boeuf and Genet observed that the young, tender leaves were less damaged than the older mature leaves. Their experiments on detached orange leaves indicated very clearly that the older leaves lost more water than the younger, whether estimated upon the basis of the original water content or upon water loss per unit area. The leaves of lemon and mandarin, although they contain less water than the orange, transpire more water. The shaddock transpires a little less and the bigarade least of all, though it has little power to conserve water. Boeuf and Genet advanced the theory that the stomata of young leaves were more plastic and permitted them to close more perfectly when the leaves were being dried out rapidly. They further remark that the practice of budding orange on bigarade root produces a tree in which there is a minimum of channels for the passage of water. The union with bigarade may give the orange superior flavor, but it may lower its resistance to drought conditions.

In the West Indies the lime tree may suffer injury from hot south winds during the winter. Chalot and Deslandes (1914) reported that windbreaks are advantageous wherever lime trees are grown in Dominica. Protection from desiccating winds is essential for the successful culture of the lime tree in the West Indies, according to Mason (1923). He reported that after becoming established the trees thrive for about 10 years, then the trees most exposed to the descciating blast of the trade winds begin to show signs of die-back, which in a few years may involve the entire grove. In Montserrat and Dominica the lime tree makes its most rapid vegetative growth from January to August when the rainfall is at a minimum. Coupled with the deficiency of soil moisture, the aridity is increased by the vigor with which the trade winds blow at that time.

Reports of the levanto of the Canary Islands (anonymous, 1920) and of the siroccos of Palestine (Georgii, 1920) depict wind effects which are similar to those which accompany northers in California.

Young (1926) reported the effect of northers on the quality of fruit harvested in 1926 in a mature Valencia orange grove. This grove was not so badly damaged as to represent an extreme case; 
many other groves suffered greater losses. The east half of the grove received good protection from a windbreak, which failed, however, to afford much protection to the west half, where many trees were damaged so severely by the wind that they bore little fruit. The grades of fruit when harvested were as follows, expressed as percentages:

\begin{tabular}{l|c|c|c|c} 
& Fancy & Extrachoice & Choice & Standard \\
\cline { 1 - 4 } & per cent & per cent & per cent & per cent \\
East half & 13.0 & 61.0 & 21.0 & 5.0 \\
West half & $\mathbf{5 . 0}$ & 49.6 & 35.6 & 9.8 \\
\hline
\end{tabular}

\section{FIELD OBSERVATIONS6}

Injury to Leaves and Twigs.-The most conspicuous as well as the most lasting injury to orange trees caused by northers is the defoliation illustrated by figure 1, which shows many branches leafless and others on which the leaves were killed. Examination of the foliage showed several distinct types of injury, the most common being $(a)$ windburn and $(b)$ scorch. Leaves killed by windburn are green, rolled, and brittle; those killed by scorch are brown and adhere to the twigs for several weeks.

Leaves killed by windburn first show wilting, then dry out quickly and become brittle before the end of the first day of wind. Death appears to be due chiefly to the withdrawal of water at a faster rate than the vascular system of the stem can replenish it. If the wind ceases after a few hours the wilted leaves sometimes recover, but if desiccation proceeds beyond a certain point no recovery is made. Mature orange leaves are killed more quickly by windburn than the young leaves. By far the largest number of leaves killed by desiccating winds succumb to windburn. In a few days the dead leaves fall to the ground.

Scorch is more often produced when the wind is hot. Wilting is not necessarily an intermediate stage of scorching; on the contrary, the blade of a scorched leaf may turn brown and become brittle in a few hours. Its color is similar to that of a leaf which has been killed by immersion for a few minutes in boiling water. Analyses made by Haas (Haas and Reed, 1927) showed that there was more insoluble nitrogen in the dry matter of injured than of uninjured

6 The Villa Park Orchards Association cooperated with the Citrus Experiment Station in most of the field work. It is a pleasure to acknowledge the great help which they rendered and the personal favors shown by the president, Mr. Willard Smith, and the manager, Mr. H. D. Nichols. 
orange leaves. This may mean that death was in part due to the coagulation of proteins of the protoplasm. $\Lambda$ leaf wilted even for a long time may rexover when adequate water is supplied from the shoot, but a scorched leaf never recovers. Leaves which have succumbed to scorch remain attached to their twigs for several weeks, even though exposed to hard winds (fig. 2). During the period of attachment they give off water at the expense of the supply in the tree.

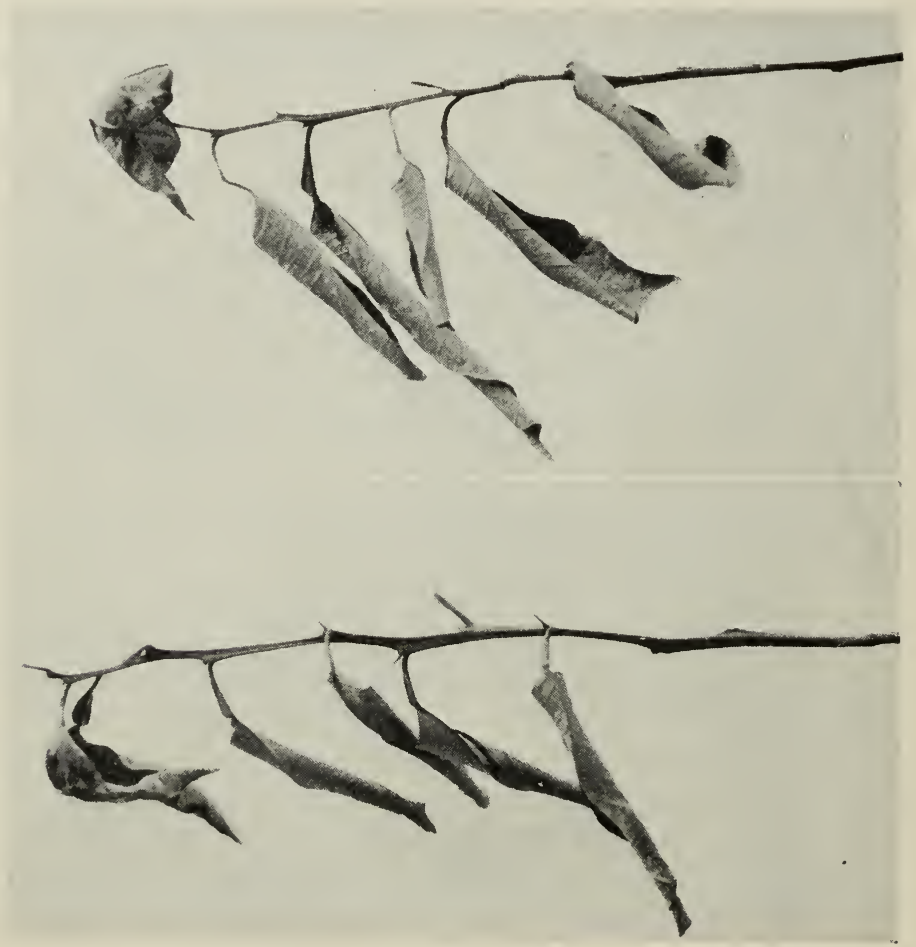

Fig. 2.-Twigs and leaves of Valencia orange which were killed by scorch produced by a norther October 12 to 14, 1923. This photograph, taken 4 weeks later, shows how the leaves drooped and died, but were not shed from the tree.

One of the most serious effects of scorch is the extensive death of the small twigs of orange trees. The scorched leaves send a stream of brown viscous material downward which, within a few days after a norther, causes the death of the twigs which receive it. This brown viscous material may be seen in the fibrovascular bundles if one removes a thin section of cortex from an affected twig. The toxic effects of this material extend laterally some distance from the fibrovascular bundles in which it moves. 
Gum formation had taken place in these twigs, as described in a later section of this paper. The small twigs are frequently killed on the windward side of the tree. The effect of this is to limit the principal growth to branches on the leeward side of the tree. Many orange trees in exposed groves are very unsymmetrical in form because of the repeated killing of twigs on the windward side of the tree.

The leaves of orange and lemon trees are often blown off by the mechanical force of the wind. Lemon leaves generally separate at the abscission layer between petiole and blade. Twigs defoliated in this manner seldom die.

Both leaves and bark on the windward side of young shoots may be, killed if the winds carry a considerable amount of sand. This was an important effect of the norther of November 20, 1919 (Reed, 1920) when the epidermal layers of shoots and fruits were killed by the impact of wind-blown sand. The injury may be increased if Colletotrichum subsequently invades the injured shoots and causes die-back and wither-tip.

New leaves appear in due course of time from buds on the living twigs. When defoliation occurs as a result of November or December northers the new foliage does not appear until the vegetative activity is renewed in February or March, but in case of the norther of October 12, 1923, there was time for the production of new foliage 5 or 6 weeks later, because the trees had not then entered on their dormant period. The growth of new shoots and leaves in such cases may be accelerated by the application of adequate amounts of irrigation water as soon as possible after defoliation occurs. In 192:? the development of new leaves was accelerated on defoliated trees which had been sprayed with whitewash.

The leaves produced on an orange tree after defoliation are generally undersized and show the condition known as foliocellosis, or 'mottle leaf.' Haas and Reed (1927) called attention to the probability that the foliocellosis was due to the loss of calcium incident to the defoliation of the trees. Apparently the shoots were unable to obtain sufficient calcium from the soil to produce healthy leaves in the period immediately following defoliation. However, the leaves produced on the succeeding cycles of growth were healthy and reached the usual size.

Effects of Northers on the Fruit.-The fruits sway to and fro during a windstorm, striking other objects which seratch or bruise them. Scars lower the commercial value of the fruit and cause financial loss in addition to that caused by fruit blown off. Fawcett and Lee (1926) have shown that the abrasions resulting from winds 
afford opportunity for fungi to infect the fruit and cause decay. When fruit is bruised the subepidermal oil glands are often ruptured, allowing the oil to escape and kill the neighboring cells of the rind. If the surrounding tissues subsequently grow in thickness the bruised area is marked by a depression.

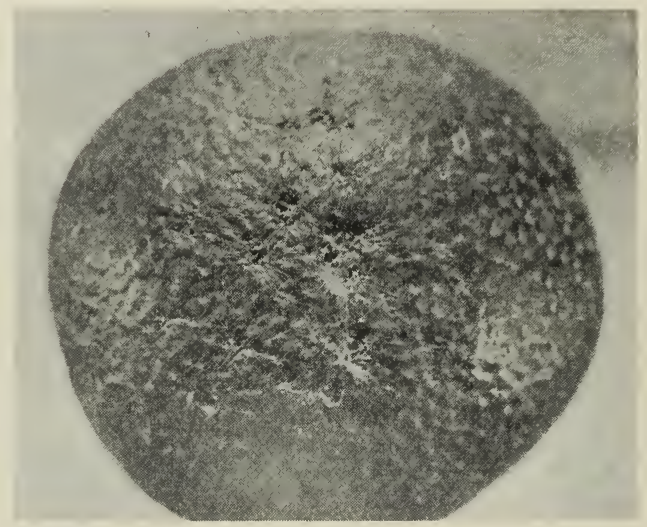

Fig. 3.-Punctures in the rind of a Navel orange caused by a hard wind which blew the orange against a thorn.
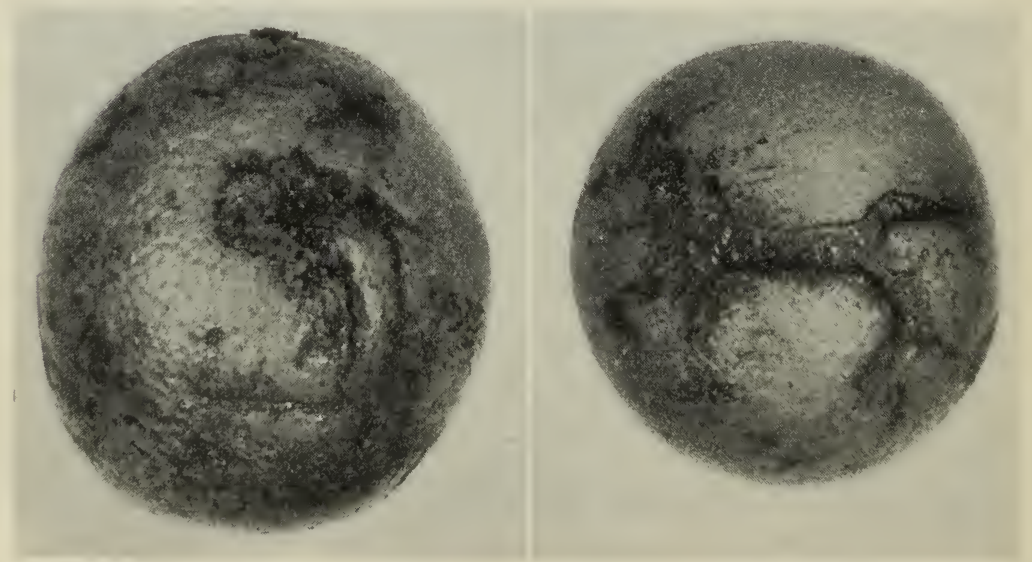

Fig. 4.--Valencia fruits scarred as a result of injuries received during severe winds.

Figure 3 shows punctures on mature Navel orange fruits resulting from wind. If such fruits are left on the tree a few weeks the cuts will heal sufficiently to prevent the entrance of decay-producing fungi. Figure 4 shows scars in Valencia fruits resulting from injuries received during severe winds. 


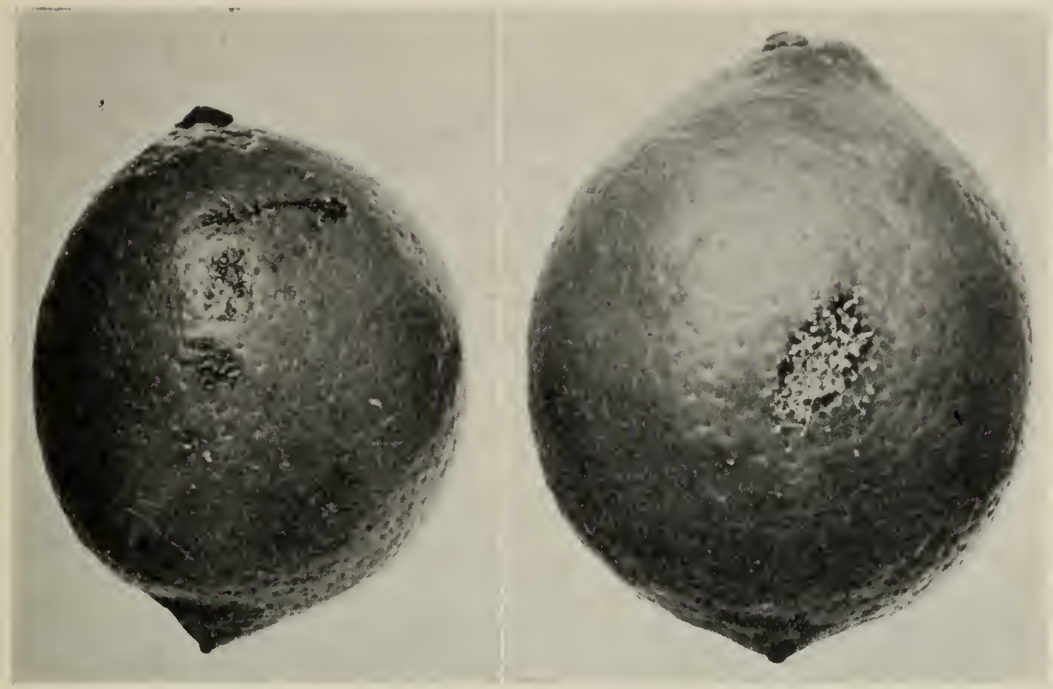

Fig. 5.-Incipient decay in stored lemons. The fungi entered through scratches and bruises that were so slight that they were not detected in the freshly picked fruit before it was placed in storage.

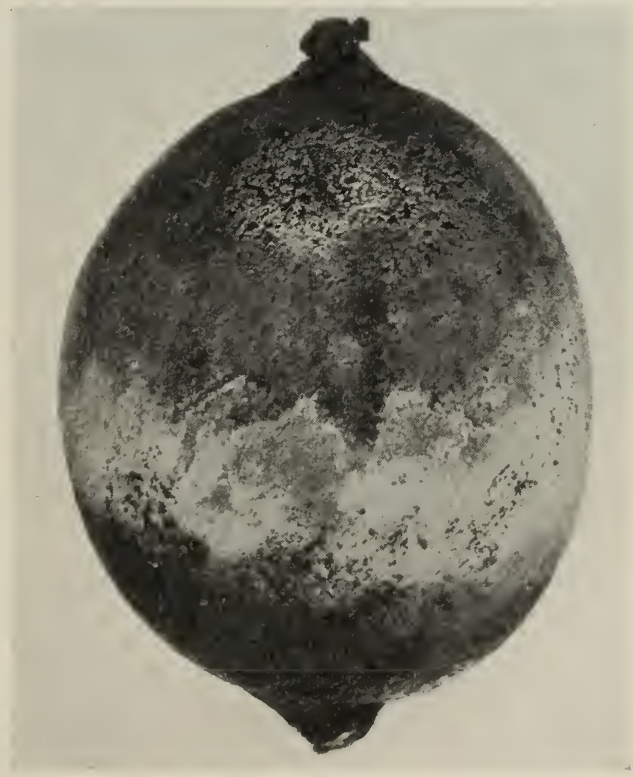

Fig. 6.-A lemon which had been bruised by contact with a limb during windstorms. Penicillium entered the rind through the bruise and caused decay. 
Lemon fruits are especially subject to injury during windstorms on account of the thorns on the branches. Figures 5 and 6 show the relation of wounds to subsequent infection with decay-producing fungi. The abrasions on the fruits shown in figure 5 were so inconspicuous that they were not detected when the fruit was graded but became evident after the fruit had been held in storage a few weeks. The fruit shown in figure 6 was extensively invaded by a fungus which gained entrance through a bruise resulting from impacts with a branch. Tholn-pricks in immature fruits may be covered with a growth of cork cells which prevent the entrance of fungi, but the fruit is rough and unsightly (fig. 7).

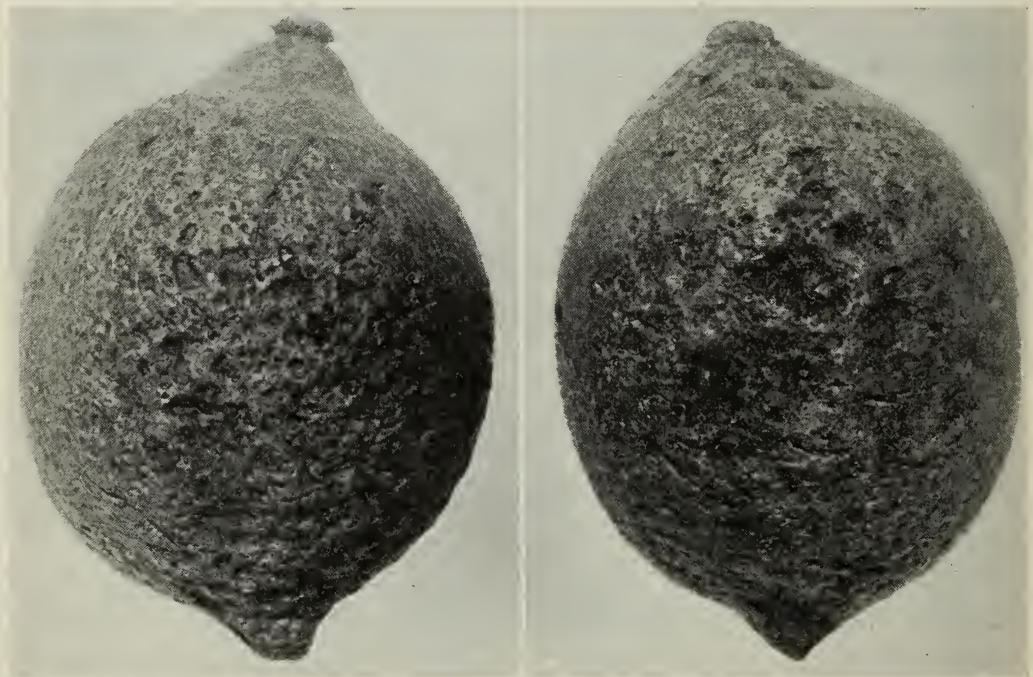

Fig. 7.-Rough, unsightly lemons from trees in situations exposed to winds. The fruits, when young, were beaten against thorns. Later the abrasions were covered by cork layers, but the scars persisted.

Certain general observations lead to the conclusion that northers, aside from producing surface blemishes and making the fruit more susceptible to diseases, result in the reduction of its size and quantity. The following may be cited as reasons for drawing this conclusion: (a) the fruits that remain on the defoliated twigs appear to be dwarfed; $(b)$ foliocellosis, which often characterizes the new leaves produced by these twigs would appear to be unfavorable for the production of large fruits; $(c)$ the amount of carbohydrates is reduced because of the loss of foliage; $(d)$ during periods of water deficit the leaves remove water from the fruits and cause definite volume decreases which may not be restored for some time if the moisture 
content of the soil is sub-optimal (Bartholomew, 1926, Waynick, 1927, 1928), and $(e)$ it seems logical to conclude that such shrinkages in fruit sizes are an outward indication of eritical losses sustained by the tree as a whole. Temperature and other factors influence the subsequent recovery and growth of the fruit. For example, Waynick believed that the freezing temperature on December 24, 1924, following the windstorms of November, gave the growth of the fruits an added check, which they were never able to counteract entirely.

Crop Yields in Relation to the Prevalence of Injurious Winds.The question of the effects of northers on volume of crop and the proportion of large-sized fruits has often been raised, but so far as the writers are aware, no very definite answer has been given. The factors cited in the preceding paragraph would certainly lead one to expect a reduction in the volume of erop and fruit sizes as a result of northers. The data about to be presented deal with this question. It is somewhat surprising that they do not give an absolutely unequivocal answer, but biological processes are complex and results must always be interpreted with caution. Part of the difficulty in this case arises from the fact that certain factors which counteract the depressing effect of the winds are difficult to express in a quantitative manner. It will be profitable, however, to present and analyse the data. In so far as possible their significance for this problem will be discussed and the indefinite or doubtful value of certain results indicated.

The data in tables 1 and 2 cover a rather limited period but they include 2 years of rather severe northers, namely, 1923 and 1927. Table 1 was compiled from figures kindly furnished by Mr. L. D. Palmer, Manager of the Orange County Fruit Exchange, and they embrace the shipments of all associations in that Exchange. The

TABLE 1

Orange County Fruit Exchange Shipaents of Valencia Oranges Classified According to Sizes

\begin{tabular}{|c|c|c|c|c|c|c|}
\hline \multirow{3}{*}{ Year } & \multicolumn{5}{|c|}{ Number of fruits per standard California box } & \multirow{3}{*}{$\begin{array}{l}\text { Total number } \\
\text { of boxes } \\
\text { shipped, } \\
\text { in thousands, } \\
\text { (ooo omitted) }\end{array}$} \\
\hline & $\begin{array}{c}100 \text { and } \\
126\end{array}$ & $\begin{array}{c}150 \text { and } \\
176\end{array}$ & $\begin{array}{c}200 \text { and } \\
216\end{array}$ & $\begin{array}{c}252 \text { and } \\
288\end{array}$ & $\begin{array}{l}324 \text { and } \\
\text { smaller }\end{array}$ & \\
\hline & \multicolumn{5}{|c|}{ Per eent of sizes shipped } & \\
\hline 1920 & 12 & 33 & 34 & $1 i$ & 4 & $11+0$ \\
\hline 1924 & 4 & 18 & 36 & 34 & 8 & 1490 \\
\hline 1925. & 8 & 26 & 33 & 26 & 7 & 600 \\
\hline 1926. & 5 & 32 & 41 & 19 & 2 & 1910 \\
\hline 1927 & 6 & 27 & 38 & $29^{*}$ & & 2000 \\
\hline 1928 & 7 & 34 & 37 & 19 & 3 & 1290 \\
\hline
\end{tabular}

* This ineludes "252 per box" and all smaller sizes which were not separately recorded in 1927. 
TABLE 2

Villa Park Orchards Association Shipments of Valencia Oranges, Classified According to Size

\begin{tabular}{|c|c|c|c|c|c|c|}
\hline \multirow{3}{*}{ Year } & \multicolumn{5}{|c|}{ Number of fruits per standard California box } & \multirow{3}{*}{$\begin{array}{l}\text { Total number } \\
\text { of boxes } \\
\text { shipped, } \\
\text { in thousands } \\
\text { (ooo omitted) }\end{array}$} \\
\hline & $\begin{array}{c}100 \text { and } \\
126\end{array}$ & $\begin{array}{c}150 \text { and } \\
176\end{array}$ & $\begin{array}{c}200 \text { and } \\
216\end{array}$ & $\begin{array}{c}252 \text { and } \\
288 \\
\end{array}$ & $\begin{array}{l}324 \text { and } \\
\text { smaller }\end{array}$ & \\
\hline & \multicolumn{5}{|c|}{ Per cent of sizes shipped } & \\
\hline$\overline{1923 \ldots}$ & 6 & 25 & 39 & 22 & 8 & 142 \\
\hline 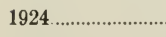 & 1 & 11 & 33 & 43 & 12 & 207 \\
\hline $1925 \ldots$ & 7 & 23 & 33 & 29 & 8 & .86 \\
\hline $1926 \ldots$ & 3 & 24 & 42 & 26 & 5 & 256 \\
\hline $1927 \ldots$ & 3 & 16 & 38 & $43^{*}$ & & 230 \\
\hline $1928 \ldots$ & 6 & 30 & 38 & 21 & 5 & 138 \\
\hline
\end{tabular}

* This includes "252 per box" and all smaller sizes, which were not separately recorded in 1927.

percentage of fruit in sizes " 100 " and " 126 " is variable. The low percentage in 1924 may be interpreted as due largely to the severe norther of October, 1923, but in part also to the larger crop. The percentage of 150 's and 176 's is perhaps a better index of size than the foregoing. It was high in 1923, 1926, and 1928. In 2 of these years the volume of the crop was less than the average, and the larger sizes may be due to that. Conversely the percentage of small fruits was small in these same years. In 1926 both the volume of the crop and the sizes were large in spite of several northers in 1925. Some other factor must have been operative which insured good growth and counteracted the adverse conditions. In the year 1925 when the volume of the crop was very small there was no corresponding increase in the percentage of large sizes. It seems logical to assume that the prevalence of northers in 1923 and 1924 contributed to this result, since the percentage of fruit larger than 200's was practically the same as in 1927 when, with a very large crop, there had been no serious injury from northers in the preceding fall.

The crops for 1923 and 1924 are suitable for comparison, being of the same order of magnitude. The 1924 crop suffered from the norther of October, 1923, and the smaller percentage of fruit in the larger sizes appears to reflect the injury. The percentages of fruit larger than 200's gives a total of 45 per cent for 1923 and 22 per cent for 1924. Adding the percentages of sizes from 200 to 288 inclusive gives a total of 51 per cent for 1923 and of 70 per cent for 1924 . This is clearly a greater difference than can be ascribed to the difference in the size of the two crops.

The comparison of the sizes in 1927 and 1928, however, does not give so clear an indictment of the winds. On the contrary, the 1927 
crop had 67 per cent of the fruit graded as 200 and smaller, while the 1928 crop had 59 per cent of the same sizes. The differences are not great enough to warrant making any statements about the effect of the winds of December, 1927.

Since the figures for the Orange County Exchange include many localities which are very slightly affected by northers, together with others which are more exposed, a study of similar figures for a single citrus association (the Villa Park Orchards Association) in a more exposed district was made. The results (table 2) were not, however, very different from those previously cited for the entire Orange County Exchange. In 1923 the percentage of large sizes (less than 200 per box) was 31 , and in 1924 it was only 12 . The difference is significant and is in favor of the 1923 crop. In 1927 the percentage of most desirable sizes was 19 and in 1928 it was 36 , the difference being in favor of the $1928 \mathrm{crop}$, although it was exposed to much greater wind damage than the 1927 crop. The norther in 1927 stripped off. many fruits, greatly reducing the volume of the crop, and as a result the size attained by fruits on the leeward side of the trees was probably increased.

The total numbers of boxes shipped in 1924 and in 1927 were comparable. The former crop suffered from the bad norther of 1923, but the latter suffered no injury from winds. The 1924 crop had only 12 per cent of fruit in the larger sizes and the 1927 crop had 19 per cent. The difference is not large, but is in favor of the latter crop.

The correlation between sizes and volume of the crop may be defined by the coefficient $r$, which is in common statistical use. The principal objection to its use in the present case is the fact that records are available for only 6 years, but this is offset to some extent by the fact that the records include the yields from groves on a variety of soils under various systems of irrigation and tillage.

The coefficient of correlation between size of crop and size of fruit for the Orange County Fruit Exchange was

$$
r=0.139 \pm 0.027
$$

and for the Villa Park Orchards Association was

$$
r=-0.119 \pm 0.006
$$

One of the coefficients is positive and the other is negative, and the magnitude of both is so low as to be without statistical significance. So far as these records go, there is no evidence that a small crop of fruit will contain a larger proportion of large sizes, or vice versa. Further study of this important question is greatly needed. 
When the quality of the fruit is considered, the effects of the winds are often evident in bruised and scratched surfaces which lower the grade. The difference due to the protection of a windbreak has been described earlier in this paper. The quality of fruit in different years, however, cannot always be correlated with the prevalence of winds. The figures in table 3 were kindly furnished by Mr. H. D.

TABLE 3

Quality of Valencja. Oranges in Three Consecutive YearsVilita Park OR.hHards Association

\begin{tabular}{|c|c|c|c|}
\hline & \multicolumn{3}{|c|}{ Year } \\
\hline & 1926 & 1927 & 1928 \\
\hline Number of boxes packed.. & 255,626 & 230,290 & 137,688 \\
\hline Grades & \multicolumn{3}{|c|}{ Per cent } \\
\hline$\overline{\text { Fancy... }}$ & 1.4 & 1.9 & 1.6 \\
\hline Extra choice & 53.6 & 67.5 & 66.6 \\
\hline Choice. & 444 & 28.7 & 318 \\
\hline Standard... & 0.6 & 1.9 & 0.0 \\
\hline
\end{tabular}

Nichols, Manager of the Villa Park Orchards Association. They give the percentage of fruit in the four grades (without reference to size) for the years 1926, 1927, and 1928.

The crops of 1926 and 1928 had been exposed to wind injury in the preceding fall, but that of 1927 was not (see tables 7 and 8 ). The volume of the crops of 1926 and 1927 was of the same order; however, there was much more fruit in the best grades in the crop of 1927 . The quality of the crop of 1928 appears to have been as high as that of 1927 even though exposed to the northers in December, 1927, but the quantity was only about 60 per cent of the 1927 crop. Since the winds principally blow off fruits from the outside and top portions of the tree there is a preponderance of 'inside' fruit in a year like 1928. The good quality of the surviving fruits may not, however, compensate for the reduction in the volume of the crop.

For comparison and confirmation the records of Valencia yields in 1927 and 1928 obtained at the Citrus Experiment Station at Riverside (table 4) will be added. The Valencia trees are in the area of the fertilizer experiments and are unprotected by windbreaks. In 1927 the fruit graded 81 per cent Fancy and 19 per cent Choice. In 1928 it graded 76 per cent Fancy and 24 per cent Choice. Obviously there was no significant difference, yet the crop of 1928 was only 62 per cent as large as the crop in 1927. 
The well-known harmful effects of northers on the fruit may be modified by other causes whose operation is difficult to measure.

Relation of Rootstock to Wind Injury.-During the course of this study several attempts have been made to ascertain whether a particular rootstock gave the trees increased ability to withstand the desiccating winds. The report of Boeuf and Genet (1906) that oranges on bigarade (Citrus aurantium) roots have lower resistance to the desiccating winds of autumn has been noted. Unfortunately trees which could be fairly compared for foliage susceptibility were not available for this study. Differences in soil or in irrigation always occurred which invalidated comparisons.

TABLE 4

Valencia Oranges, Citrus Experiment Station Grove. Quality and Grades of FrutT in 1927 And 1928

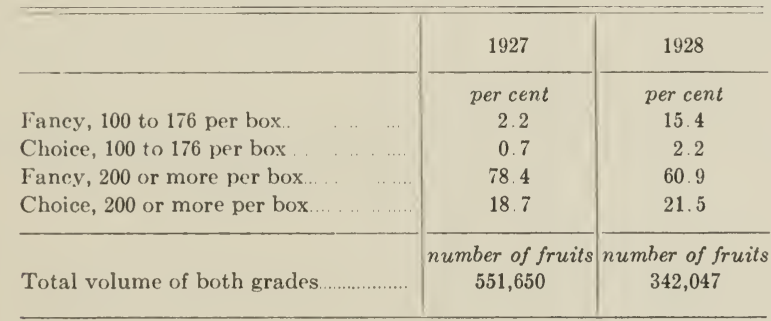

Some records were obtained, however, on the relation of rootstock to abscission of fruit of Navel oranges following a norther on November 22 and 23, 1924, on plot $V$ in the rootstock plots of the Citrus Experiment Station. Most of this fruit fell about 10 days after the windstorm and fell as the result of an abscission layer formed between the twig and pedicel. The average weight of oranges lost per tree on the sweet orange stock was $4.85 \pm 0.37 \mathrm{lbs}$; on the sour orange stock, $6.92 \pm 0.46 \mathrm{lbs}$; ; and on the trifoliate orange stock $20.45 \pm 2.15$ lbs. In this case the difference between sweet and sour stock is not significant, but the loss from trees on trifoliate stock was considerable. These figures are introduced, not because trifoliate stock is extensively used for orchard planting, but to show that rootstock may have an influence on fruit abscission. Data on the effect of rootstock on leaf abscission would be valuable, but none are available at present.

Soil Conditions in Groves Which Were Badly Damaged.-The Villa Park Orchards Association made, at the suggestion of the writers, a series of excavations in orange groves three weeks after the extremely severe storm of October 12 to 14,1923 . The object was to demonstrate the distribution of tree roots in the soil in relation to plow sole and 
water penetration. The excavations were 4 feet deep and 7.5 to 9 feet long extending from the line of the tree row out into the middle and at right angles to the irrigation furrows. The soil conditions found by this method were very enlightening.

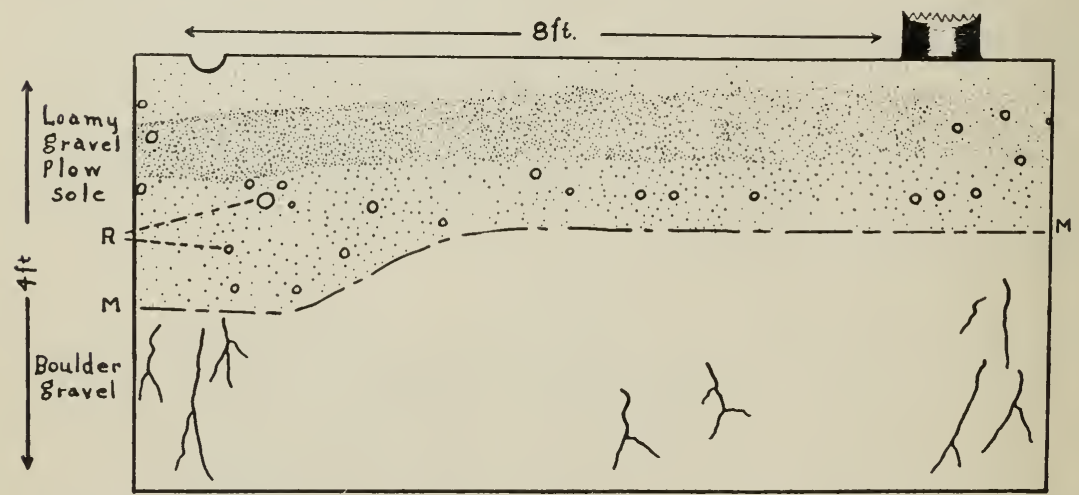

Fig. 8.-Diagram showing soil and root growth in a grove on Ramona gravelly loam. The plow sole near the surface had retarded the penetration of irrigation water. ( $M, M$ shows the depth to which soil was moist, $R$, roots which were cut.) The trees were severely injured by windburn.

On soils of the Ramona gravelly loam type there were thick plow soles through which water had penetrated with difficulty (fig. 8). The trees on these soils showed injury from windburn where the soil was dry below a depth of 18 to 24 inches from the surface. The profile in figure 8 shows one of the typical cases in which the penetration of water had been very poor even under the irrigation furrow

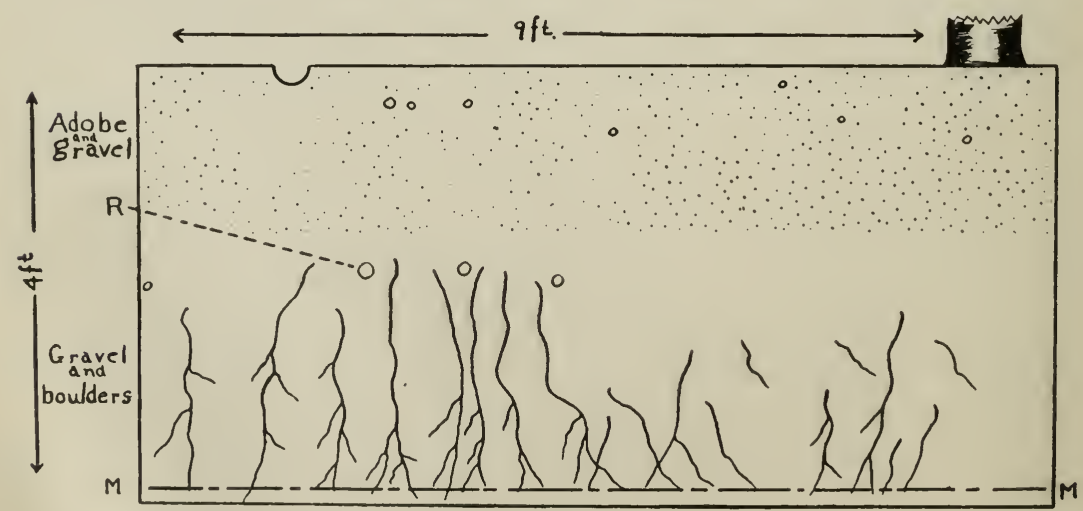

Fig. 9.-Diagram showing soil and root relations in an orange grove under successful conditions of tillage and irrigation. ( $R$, roots which were cut.) Both water and roots had penetrated beyond the 4-foot level. The trees suffered very slight injury from the wind. 
and the soil contained few roots at depths below 2 feet. In such conditions the trees were unable to meet any severe demands for water, such as those imposed on them by a norther. This type of soil readily becomes compact, especially after frequent cultivation with heavy implements. Care must be used to avoid unnecessary packing when the soil is wet.

The contrast shown in figure 9 illustrates the way in which the roots of orange trees will develop when proper tillage and irrigation methods are used. There was no plow sole in this grove and the limit of moisture penetration was below the bottom of the trench, i.e., below 4 feet. The tree roots penetrated deeply and were profusely branched, forming a mass of fibrous active roots. The trees suffered very slight injury from the winds.

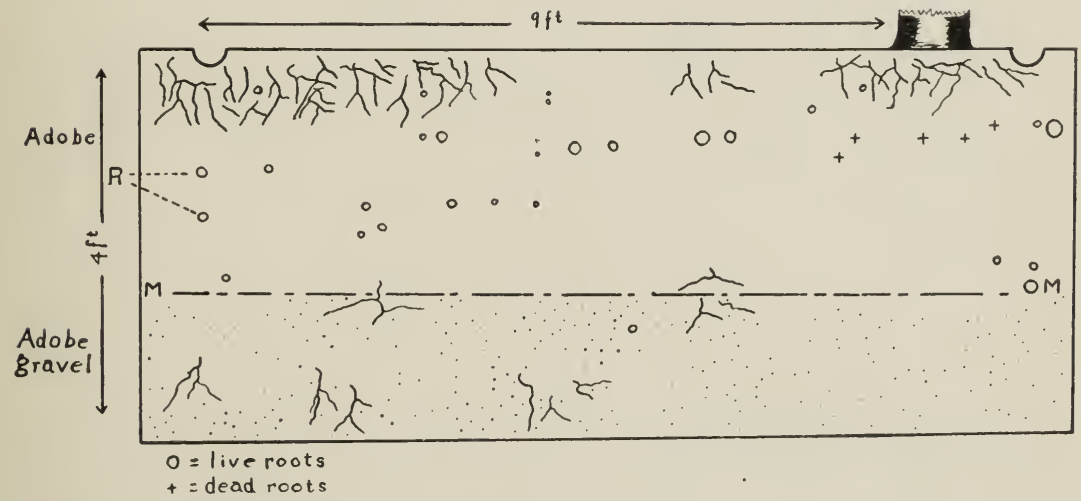

F'ig. 10.-Diagram showing soil and root growth in an orange grove on Yolo clay. As a result of excessive irrigation most of the living roots were confined to the surface layer of soil. ( $M, M$ shows depth to which soil was moist, $R$, roots which were cut.) The trees were severely injured by windburn and scorch.

On soils of the Yolo clay loam or Yolo clay there were conditions of a somewhat different nature. Plow soles were not conspicuous, but in some groves the roots of the trees had been injured by excessive irrigation. Nearly all of the deeper roots had been killed, leaving only a restricted root system near the surface (fig. 10).

$A$ few groves on heavy soil received water at intervals of 8 weeks or longer. In these there was remarkably little windburn, the soil was friable, and roots were well distributed to a depth of 4 feet or more (fig. 11).

These observations showed conclusively that a large part of the damage from windburn could be avoided by cultural and irrigation practices which promote the penetration of the water and the develop- 
ment of fine fibrous absorbing roots. This subject will be further discussed in a subsequent section, pages 50,51 , and 52 .

Other Factors Which Increase Wind Injury.-Several conditions under which the orange trees suffered increased injury from the northers were revealed in the course of the study.

a) Trees growing on soil which contained harmful amounts of alkali salts near Riverside were examined after the norther of October 12-14, 1923. Orange trees on soil which had been irrigated with saline water showed more windburn and defoliation than trees which had been irrigated with relatively pure water.

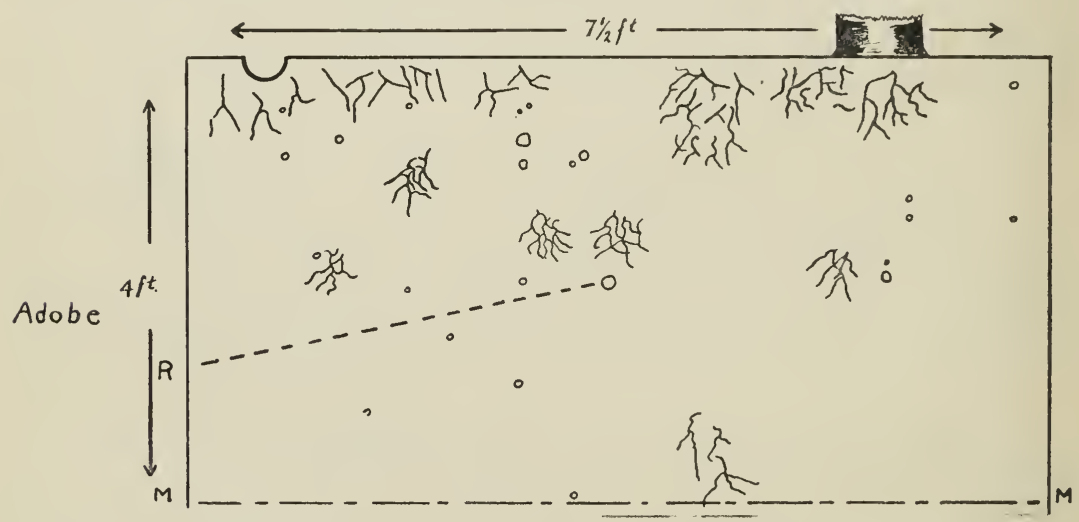

Fig. 11.-Diagram showing soil and root growth in an orange grove on Yolo clay. The soil had been carefully irrigated at intervals of 6 or 8 weeks and was moist at a depth of 4 feet. ( $M, M$ shows depth to which soil was moist, $R$, roots which were eut.) The trees were not injured by wind. Compare with figure 10.

b) Trees affected with psorosis (scaly bark) generally show increased injury because the disease impairs the water-conducting power of the wood.

c) Trees heavily infested with scale insects or previously infested with red spider (Paratetranychus citri, McG.) usually show maximum injury from northers. In districts where the summer climate is relatively cool and moist, red-spider infestations may be very heavy. If these are followed by northers in the late fall months, the injury is severe.

\section{CLIMATOLOGICAL DATA}

Meteorological Conditions During Northers.-Some data on the meteorological conditions which characterized the northers will be presented in order to define a little more exactly what is implied in the term 'norther.' 
Winds of this nature are more or less characteristic of the climate of all countries in the vicinity of elevated deserts. They blow when there is a barometric high over a large desert area and a lower pressure near the sea-coast. This difference in pressure forces the cold, dry air toward the lower coastal plain. When the difference in pressure between the two areas is considerable, the air is forced over the mountains and hills with great rapidity. In descending to the lower levels the air is subjected to compression and, as a result, its tempertaure is raised. These 'storms' are therefore accompanied by high temperatures and cloudless skies. During the storm the air temperature ranges from $70^{\circ}$ to $90^{\circ} \mathrm{F}$, the relative humidity is usually below 30 per cent, and the wind velocity from 15 to 60 miles per hour.

McAdie (1912) described the norther of December 25 and 26, 1912, which produced great injury to orange trees in California and increased the damage produced by freezing temperatures in the following January. He reported that the velocity of this norther was estimated to be 60 miles an hour in the vicinity of Wineville. Askinazy (1928) has described the conditions responsible for and accompanying the hot winds of southeastern Europe. Further data on the meteorology of these storms will be found in articles by Blair (1909) and Young (1926).

The local character of these winds is well known in California. The relocity of the wind may greatly vary at places separated by only a few miles. There is a popular belief that a norther always blows for 3 days, but their duration actually varies from 1 to 5 days. Frequently the wind blows only during the day. The average wind velocity for a 24-hour period in such case may be very different from the maximum attained, especially since northers are generally gusty winds. The windburn and scorch which have been investigated are the results of the continued desiccation rather than the intermittent gusts which produce mechanical injuries to fruit and foliage.

In southern California the maximum damage to plant life is usually found about half a mile to the leeward of a range of hills like the foothills of the Santa Ana Mountains or of the Chocolate Mountains. Sometimes the wind seems to pour over the hills like a cataract and to descend almost vertically on the tree-tops. Severe injury of this type was produced in November, 1919, when the wind came over the top of the Sierra Madre Range.

Northers Occurring from 1923 to 1929.-The writers made a series of observations upon northers extending from October, 1923, to the beginning of January, 1929. During much of this time instruments 
were maintained at Villa Park, which were operated by Messrs. Nichols, Collins, and Adams of the Villa Park Orchards Association. Records of meteorological conditions at the Citrus Experiment Station, Riverside, were taken from data furnished by the department of Orchard Management. The Fontana records were kindly furnished by Mr. J. R. Lundemo of the Fontana Land and Water Company, part of the Newport Harbor records were furnished by Mrs. Marta Deraga, the El Centro records by Mr. J. H. Gordon, Meteorologist, United States Weather Bureau Office, Yuma, Arizona, part of the Mount Wilson records were furnished by Dr. W. S. Adams, Director of the Mount Wilson Observatory. The remaining records were furnished by Mr. R. L. Fisher, Assistant Meteorologist in the United States Weather Bureau Office, Los Angeles. To all of these persons we wish to acknowledge our indebtedness for their kind cooperation.

Temperature and relative humidity of the air at Riverside, Fontana, and Villa Park were obtained from recording hygro-thermographs housed in standard Weather Bureau shelters in orchards. The thermograph was frequently corrected by an accurate mercury thermometer and the hygrograph by a sling psychrometer. The temperature data for El Centro were taken from the readings of the dry-bulb thermometer at noon and those of the relative humidity were computed from the differences between the wet and dry-bulb thermometers at noon. The relative humidity was recorded in the tables for noon instead of the usual Weather Bureau readings at 5 A.M. and 5 P.M. The noon readings seemed to be more representative of the 24-hour period, though it did not always coincide with the minimum.

A certain amount of error is undoubtedly present in the humidity records obtained from hair hygrographs, although they were checked frequently by the sling psychrometer. No great disparities in the records were found, however.

The norther of October 12 to 14, 1923, was one of the most destructive storms of recent years. It came so early in the season that the hygrograph had not been insalled at Villa Park, but maximum temperature records for that locality were kindly furnished by $\mathrm{Mr}$. William Bathgate. The temperature at all localities named in table 5 was high through the whole storm period. The humidity at Riverside was relatively low and at Villa Park it was probably lower. The humidity of the air at Fontana was not extremely low, but wind movement was moderately high. The wind was gusty and frequently formed eddies which are not measured by the average-velocity figures. The resulting damage to citrus trees in southern California was widespread and certainly amounted to more than a million dollars. A 
few days after the storm the injury was apparent. Most of the injury was due to windburn, but scorch was produced on trees which stood in exposed places. Within a week the windburned leaves had fallen, but the scorched leaves hung on the twigs for several weeks. Five weeks later a new crop of foliage was produced on the defoliated green twigs. 'Trees which were irrigated promptly after the storm responded more quickly and completely by producing new shoots and foliage.

\section{TABLE 5}

Tharperature, Humidity, and Wind Velocity Recokds at Selected Points DURiNG A NORTHER, OCTOBER 12-14, 1923

\begin{tabular}{|c|c|c|c|c|c|c|c|c|c|}
\hline \multirow{2}{*}{ Station } & Oct. 12 & Oct. 13 & Oct. 14 & Oet. 12 & Oct. 13 & Oct. 14 & Oct. 12 & Oct. 13 & Oct. 14 \\
\hline & \multicolumn{3}{|c|}{$\begin{array}{c}\text { Maximum tempera- } \\
\text { ture, }{ }^{\circ} \mathrm{F}\end{array}$} & \multicolumn{3}{|c|}{$\begin{array}{l}\text { Relative humidity } \\
\text { (at noon) }\end{array}$} & \multicolumn{3}{|c|}{$\begin{array}{l}\text { Average wind velocity } \\
\text { miles per hour }\end{array}$} \\
\hline Mount Wilson. & 69 & 64 & $i 4$ & & & & 15 & 30 & 13 \\
\hline Newport Harbor. & 88 & 91 & 81 & & & & 32 & & 6 \\
\hline $\begin{array}{l}\text { Riverside (Citrus Experi- } \\
\text { ment Station) }\end{array}$ & 89 & 88 & 93 & & & & & & \\
\hline $\begin{array}{r}\text { Riverside (from charts of } \\
\text { U.S. Weather Bureau).... }\end{array}$ & & & & 25 & 15 & 10 & & & \\
\hline Santa Ana & 82 & 89 & 89 & & & & & & \\
\hline Villa Park ...... & 87 & 88 & 92 & & & & & & \\
\hline San Pedro & 76 & 85 & 88 & & & & 8 & 9 & 8 \\
\hline Fontana & 83 & 83 & 90 & 42 & 29 & 20 & 11 & 9 & 5 \\
\hline
\end{tabular}

The wind blew off a large quantity of immature fruit. From counts of fallen fruits losses were estimated to be 40 to 50 boxes per acre. Under the conditions it was not all loss, however, since these fruits, had they remained on the defoliated branches, would have imposed a still greater burden on the impoverished trees.

TABLE 6

Temperature, Humidity, and Wind Velocity Records at Sfelected Points During a Norther, November 22-24, 1924

\begin{tabular}{|c|c|c|c|c|c|c|c|c|c|}
\hline \multirow{2}{*}{ Station } & Nov. 22 & Nov. 23 & Nov. 24 & Nov. 22 & Nov. 23 & Nov. 24 & Nov. 22 & Nov. 23 & 3 Nov .24 \\
\hline & \multicolumn{3}{|c|}{$\begin{array}{c}\text { Maximum tempera- } \\
\text { ture, }{ }^{\circ} \mathrm{F}\end{array}$} & \multicolumn{3}{|c|}{$\begin{array}{l}\text { Relative humidity } \\
\text { (at noon) }\end{array}$} & \multicolumn{3}{|c|}{$\begin{array}{l}\text { A verage wind velocity, } \\
\text { miles per hour }\end{array}$} \\
\hline Mount Wilson. & 71 & 62 & 62 & & & & 12 & 11 & 3 \\
\hline Newport Harbor. & 77 & 86 & 78 & & & & ... & 5 & \\
\hline $\begin{array}{l}\text { Riverside (Citrus Experi- } \\
\text { ment Station) }\end{array}$ & \multirow[t]{2}{*}{90} & \multirow[t]{2}{*}{80} & \multirow[t]{2}{*}{81} & 30 & 12 & \multirow[t]{2}{*}{14} & \multirow[t]{2}{*}{10} & \multirow[t]{2}{*}{13} & \multirow[t]{2}{*}{7} \\
\hline $\begin{array}{l}\text { Riverside (U. S. Weather } \\
\quad \text { Bureau) }\end{array}$ & & & & 23 & 10 & & & & \\
\hline Santa Ana. & 86 & 82 & 79 & & & & & & \\
\hline Villa Park & 90 & 84 & 86 & 35 & 9 & 9 & & & \\
\hline San Pedro. & 86 & 80 & 76 & & & & & & \\
\hline Fontana & 87 & 71 & 75 & 34 & 20 & 23 & 23 & 13 & 1 \\
\hline
\end{tabular}


The greatest injury appeared on trees which had been inadequately supplied with water.

The most injurious norther in 1924 started on the night of November 22 and continued for two days (table 6). The temperatures at Riverside, Santa Ana, and Villa Park were nearly as high as they had been during the 1923 norther, and the humidity at these places was much lower. The wind velocity dropped considerably on the last day of the storm. The average wind relocity was moderate, although hard gusts were frequent. This storm caused windburn, but no scorch; as a resilt the dead leaves fell in a few days, leaving the twigs uninjured. The fruits beaten off by the storm dir not always separate at the calyx, in most cases the twig was twisted and broken above the fruit, causing its fall. In some instances 200 fruits per tree had been blown to the ground by the storm.

\section{TABLE 7}

Temperature, Humidity, and Wind Velocity Records at Selected Points During Three Northers in 1925 (See Table for Dates)

\begin{tabular}{|c|c|c|c|c|c|c|c|c|c|c|c|c|c|c|c|c|c|c|c|c|c|c|c|c|}
\hline \multirow{3}{*}{ Station } & \multicolumn{5}{|c|}{ Nov. } & \multicolumn{3}{|c|}{ Dec. } & \multicolumn{5}{|c|}{ Nov. } & \multicolumn{3}{|c|}{ Dec. } & \multicolumn{5}{|c|}{ Nov. } & \multicolumn{3}{|c|}{ Dec. } \\
\hline & 14 & 18 & 19 & 20 & 21 & 3 & 4 & 5 & 14 & 18 & 19 & 20 & 21 & 3 & 4 & 5 & 14 & 18 & 19 & 20 & 21 & 3 & 4 & 5 \\
\hline & \multicolumn{8}{|c|}{$\begin{array}{l}\text { Maximum tempera- } \\
\text { ture, }{ }^{\circ} \mathrm{F}\end{array}$} & \multicolumn{8}{|c|}{$\begin{array}{l}\text { Relative humidity } \\
\text { (at noon) }\end{array}$} & \multicolumn{8}{|c|}{$\begin{array}{l}\text { Average wind velocity, } \\
\text { miles per hour }\end{array}$} \\
\hline Mount Wilson.. & 56 & 61 & 63 & 61 & 58 & 52 & 55 & 61 & & & & & & & & & 10 & 7 & 7 & $\tau$ & 7 & 12 & 19 & \\
\hline Newport Harb'r & 73 & 82 & 76 & 82 & 78 & 60 & 71 & 77 & $2 i$ & 39 & 31 & 30 & 23 & 61 & 48 & 76 & 6 & 2 & 4 & 2 & 2 & 4 & $\tau$ & 15 \\
\hline $\begin{array}{l}\text { Riverside (Cit- } \\
\text { rus Experi- }\end{array}$ & & & & & & & & & & & & & & & & & & & & & & & & \\
\hline ment Station) & 76 & 79 & 82 & 81 & 81 & 70 & 70 & 78 & 17 & $\ldots$ & 14 & 19 & 20 & 25 & 27 & 30 & & & & 8 & 6 & 6 & 6 & 15 \\
\hline Santa Ana. & 71 & 70 & 78 & 81 & 81 & 64 & 70 & 73 & & & & & & & & & & & & & & & & \\
\hline Villa Park.. & 72 & 76 & 80 & 78 & $7 \gamma$ & 66 & 67 & 73 & 10 & 10 & 13 & 8 & 9 & 33 & 20 & 22 & & & & & & & & \\
\hline Sian Pedro & 70 & 69 & 75 & 82 & 81 & 68 & 69 & 70 & & & & & & & & & & & & & & & & \\
\hline Fontana... & 66 & 71 & 71 & 72 & 72 & 63 & 66 & 71 & 35 & 39 & 35 & 40 & 41 & 40 & 35 & 43 & 12 & 13 & 14 & 12 & 11 & 13 & 14 & 12 \\
\hline
\end{tabular}

There were three northers in 1925 which injured citrus trees (table 7 ). The greatest injury was caused by the storm of November 18 to 21. On November 18, 19, and 20 the wind blew moderately hard. The temperatures were moderately high at Riverside and Santa Ana but low at Fontana and Newport Harbor. The humidity at Riverside and Villa Park (fig. 12) was excessively low for a long period. These conditions produced severe windburn, but little scorch. In one orange grove a distinct type of scorch was observed, which killed only the leaf tissue in the areas between veins (fig. 13). Apparently the tissues nearest the veins could obtain enough water to meet their needs in spite of the scorching action of the wind. With higher temperatures and higher humidity the type of scorch previously described would 
have been produced. This storm was rather remarkable in having no extreme atmospheric conditions. The damage to vegetation appears to have been caused by the coincidence of the three factors which increased transpiration to a point where a critical water deficit was created in the trees. One or two of the factors alone could not have produced the injury.

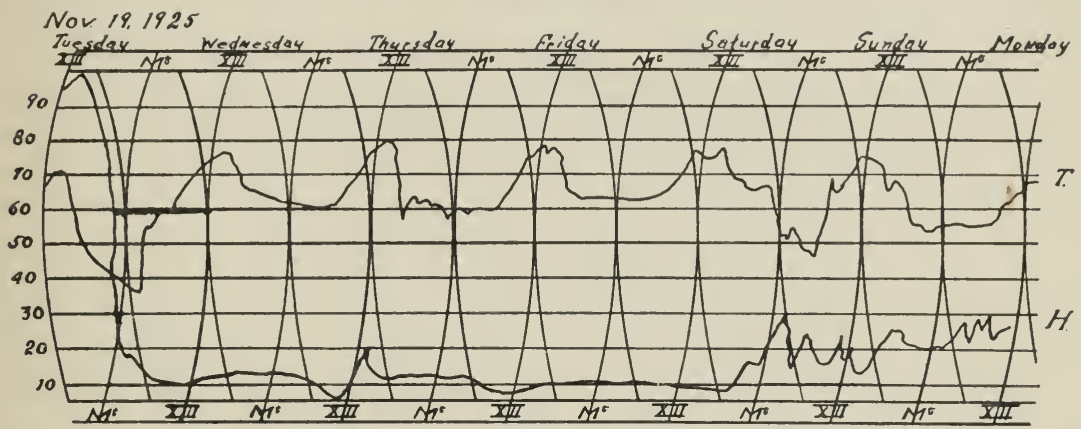

Fig. 12.-Data on temperature and humidity at Villa Park during a norther heginning November 19, 1925. Copy of the chart from the hygro-thermograph. $T$, temperature; $H$, humidity.
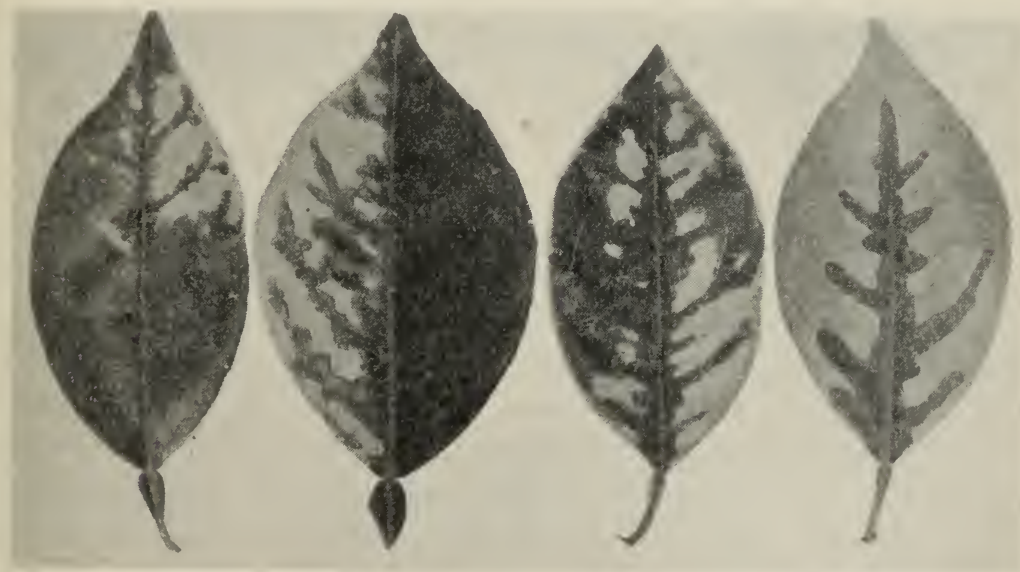

Fig. 13.--Orange leaves showing scorch produced by windstorm on November 23, 1924. Photograph made 16 days later.

There was no windburn or seorch in the citrus groves in 1926 but there was serious mechanical injury from a windstorm on December 23 and 24 when branches were broken and trees uprooted by the wind. The wind followed a storm which gave some precipitation of rain on the lowlands and of snow in the adjacent mountains, thus affording a certain amount of atmospheric humidity. At the Citrus 
Experiment Station the mean velocity was 11 miles an hour for the 24-hour period, but in places near the foot of the San Gabriel mountains the maximum velocity was much higher, with correspondingly greater damage to trees. Large quantities of leaves and fruits were blown from the trees, not only in districts customarily injured but in districts considered exempt. Many tons of fruit were salvaged, but nevertheless the total loss was large.

TABLE 8

Temperature, Humidity, and Wind Velocity Records at Selected Points During Two Northers in 1927 (See Table for Dates)

\begin{tabular}{|c|c|c|c|c|c|c|c|c|c|c|c|c|}
\hline \multirow[b]{3}{*}{ Station } & \multicolumn{4}{|c|}{ December } & \multicolumn{4}{|c|}{ December } & \multicolumn{4}{|c|}{ December } \\
\hline & 3 & 4 & 17 & 18 & 3 & 4 & 17 & 18 & 3 & 4 & 17 & 18 \\
\hline & \multicolumn{4}{|c|}{$\begin{array}{l}\text { Maximum tempera- } \\
\text { ture, }{ }^{\circ} \mathbf{F}\end{array}$} & \multicolumn{4}{|c|}{$\begin{array}{l}\text { Relative humidity } \\
\text { (at noon) }\end{array}$} & \multicolumn{4}{|c|}{$\begin{array}{l}\text { Average wind velocity, } \\
\text { miles per hour }\end{array}$} \\
\hline Mount Wilson........ & 68 & 57 & 45 & 40 & & & & & 17 & 22 & 27 & 17 \\
\hline Newport Harbor.. & 79 & 75 & 62 & 61 & 69 & 7 & 4 & 13 & & 9 & ........... & 6 \\
\hline $\begin{array}{r}\text { Riverside (Citrus } \\
\text { Experiment Sta- } \\
\text { tion) }\end{array}$ & \multirow[t]{2}{*}{84} & \multirow[t]{2}{*}{67} & \multirow[t]{2}{*}{63} & \multirow[t]{2}{*}{57} & 20 & 19 & 22 & 20 & & \multirow[t]{2}{*}{14} & \multirow[t]{2}{*}{18} & \multirow[t]{2}{*}{7} \\
\hline $\begin{array}{l}\text { Riverside (U. S. } \\
\text { Weather Bureau }\end{array}$ & & & & & 17 & 12 & 7 & $\mathbf{5}$ & & & & \\
\hline Santa Ana & 88 & 84 & 68 & 63 & & & & & & & & \\
\hline Villa Park......... & 84 & 74 & 60 & 62 & 20 & 25 & 27 & 25 & & & & \\
\hline San Pedro.......... & 78 & 77 & 63 & 60 & & & & & 11 & 14 & 18 & 5 \\
\hline Fontana.............. & 82 & 68 & 60 & 58 & 25 & 27 & 37 & 35 & & 9 & 13 & 17 \\
\hline
\end{tabular}

In 1927 extensive windburn and scorch were produced by a norther on December 3 and 4 (see table 8 ). Although relatively late in the season, the trees were more severely damaged than by any storm since October, 1923. The wind velocity was very high during the storm. There seemed to be a broad current of air movement over the entire range of mountains on the north instead of strong currents through the passes. The temperature during this storm was not excessively high nor was the air humidity excessively low (fig. 14), nevertheless the trees suffered severe injury from the death of foliage. For a period of several weeks preceding the storm there had been high temperature coupled with low humidity. As a result, the water content of the soil had been greatly reduced. Many of the growers were unaware of the condition of the soil and failed to give it adequate irrigation. No rain had fallen since November 13, when there was a precipitation of 0.02 -inch at Riverside and 0.13 at Santa Ana. The effects of this light rain were dissipated long before the norther started on December 3. 
In a certain sense the effects of this storm were cumulative, the preceding weeks having brought the moisture in the soil to the critical wilting point, and when the norther started the trees could not obtain water to meet the deficit caused by rapid losses.

Another north wind on December 17 and 18 added to the injury already produced, but was somewhat beneficial because it removed leaves scorched by the preceding storm.

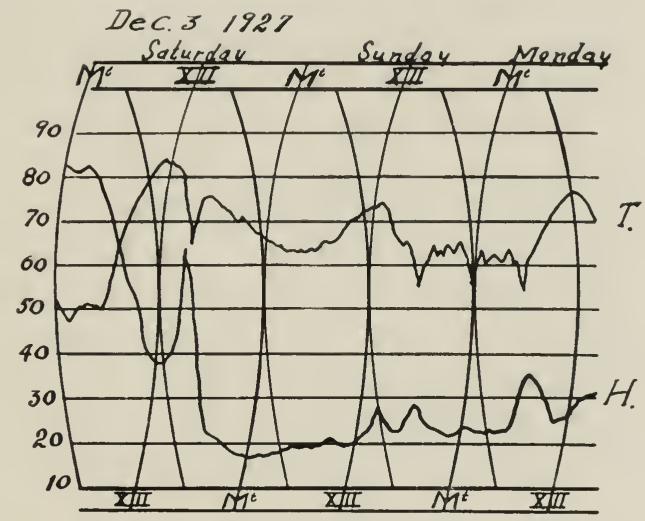

Fig. 14.-Data on temperature and humidity at Villa Park during a norther, December 3 and 4, 1927. Copy of the chart from the hygro-thermograph. $T$, temperature; $H$, humidity.

In 1928 the injury by northers was less severe than in the preceding year, although citrus trees suffered windburn in certain places. As shown in table 9, there was a norther which started on November

TABLE 9

Temperature, Humidity, and Wind Velocity Records at Selected Points During a Norther, November 17-21, 1928

\begin{tabular}{|c|c|c|c|c|c|c|c|c|c|c|c|c|c|c|c|}
\hline \multirow{3}{*}{ Station } & \multicolumn{5}{|c|}{ November } & \multicolumn{5}{|c|}{ November } & \multicolumn{5}{|c|}{ November } \\
\hline & 17 & 18 & 19 & 20 & 21 & 17 & 18 & 19 & 20 & 21 & 17 & 18 & 19 & 20 & 21 \\
\hline & \multicolumn{5}{|c|}{$\begin{array}{l}\text { Maximum tempera- } \\
\text { ture, }{ }^{\circ} \mathrm{F}\end{array}$} & \multicolumn{5}{|c|}{$\begin{array}{l}\text { Relative humidity, } \\
\text { (at noon) }\end{array}$} & \multicolumn{5}{|c|}{$\begin{array}{l}\text { Average wind veloc- } \\
\text { ity, miles per hour }\end{array}$} \\
\hline Mount Wilson & 56 & 56 & 59 & 59 & 60 & 19 & 20 & 13 & 16 & 20 & 22 & 9 & 13 & 26 & 11 \\
\hline Newport Harbor & & & & & & & & & & & & & & & \\
\hline $\begin{array}{l}\text { Riverside (Citrus Experiment Sta- } \\
\text { tion) }\end{array}$ & \multirow[t]{2}{*}{68} & \multirow[t]{2}{*}{67} & \multirow[t]{2}{*}{70} & \multirow[t]{2}{*}{77} & \multirow[t]{2}{*}{73} & \multirow{3}{*}{$\begin{array}{l}23 \\
10\end{array}$} & 15 & 24 & 12 & 19 & ........ & ....... & $\ldots \ldots$ & \\
\hline $\begin{array}{l}\text { Riverside (charts of U. S. Weather } \\
\text { Bureau) }\end{array}$ & & & & & & & 4 & 5 & 7 & 12 & & & & & \\
\hline Santa Ana. & 77 & 78 & 76 & 83 & 83 & & & & & & & & & & \\
\hline Villa Park.... & & & & & & & & & & & & & & & \\
\hline San Pedro.... & 67 & 70 & 70 & 74 & 75 & & & & & & 8 & 11 & 9 & & 9 \\
\hline Fontana & 64 & 64 & 66 & 74 & & 30 & 25 & 22 & 22 & & 11 & 16 & 15 & 17 & 9 \\
\hline
\end{tabular}


17 and lasted 5 days. The temperatures were not extremely high, but the humidity during most of the time was dangerously low and the velocity of the wind was at times (e.g., on November 20) very high. In case of a storm of this character a suitable windbreak may be expected to give maximum protection.

This short discussion on the meteorology of northers may be summarized by saying that the atmospheric conditions during the storms were characterized by high temperature, low humidity, and a strong wind. The intensity of these individual factors varies from place to place and from time to time. There appears to be no support for the opinion that the northers owe their injurious effects to frictional charges of electricity (see Young, 1926).

In the 6 years covered by these observations there have been 2 years in which there were no northers of major importance; in the other 4 years there were 2 in which northers produced very severe injury to citrus trees, involving large financial losses to the growers. One of these storms occurred in early fall and the other in late fall. The frequency and severity of these winds are factors which may largely determine whether citrus trees may be grown with profit in a given locality.

Windstorms of the Imperial and Coachella Valleys.-Special mention should be made of the effects of winds in the Imperial and Coachella valleys because they differ in some respects from those of the regions previously discussed. The injurious windstorms occur chiefly in the spring rather than in the fall months, and they are not always accompanied by low humidity. Most of the high winds in the Imperial Valley blow from the west, i.e., from the Laguna Mountains.

The data given in table 10 were from observations made by Professor John W. Cook and his students in the El Centro Junior College. Their anemometer has no recording device, consequently there is no record of maximum wind velocities, but on a day when the average wind velocity was 28 miles an hour one might expect damage even though there were no hard gusts.

On March 22 and 23, 1929, the maximum temperatures were $75^{\circ}$ and $66^{\circ} \mathrm{F}$; the percentages of relative humidity were 44 and 29 ; unfortunately there were no anemometer records of wind velocity. Mention of injury will be confined to the grapefruit, the species of citrus fruit chiefly grown in these valleys. The leaves of trees exposed to west winds suffered more or less mechanical injury, but no widespread defoliation occurred. Many leaves were frayed at the margin or split, and some were blown off. Young, immature leaves showed a type of injury which merits special notice (fig. 15). The marginal 
and apical regions of such leaves were killed by the high wind. The dead portion of the leaf tissue fell off in the course of time and the living area continued to grow, often resulting in the formation of asymmetrical leaves.

TABLE 10

High Winds at El Centro, 1927*

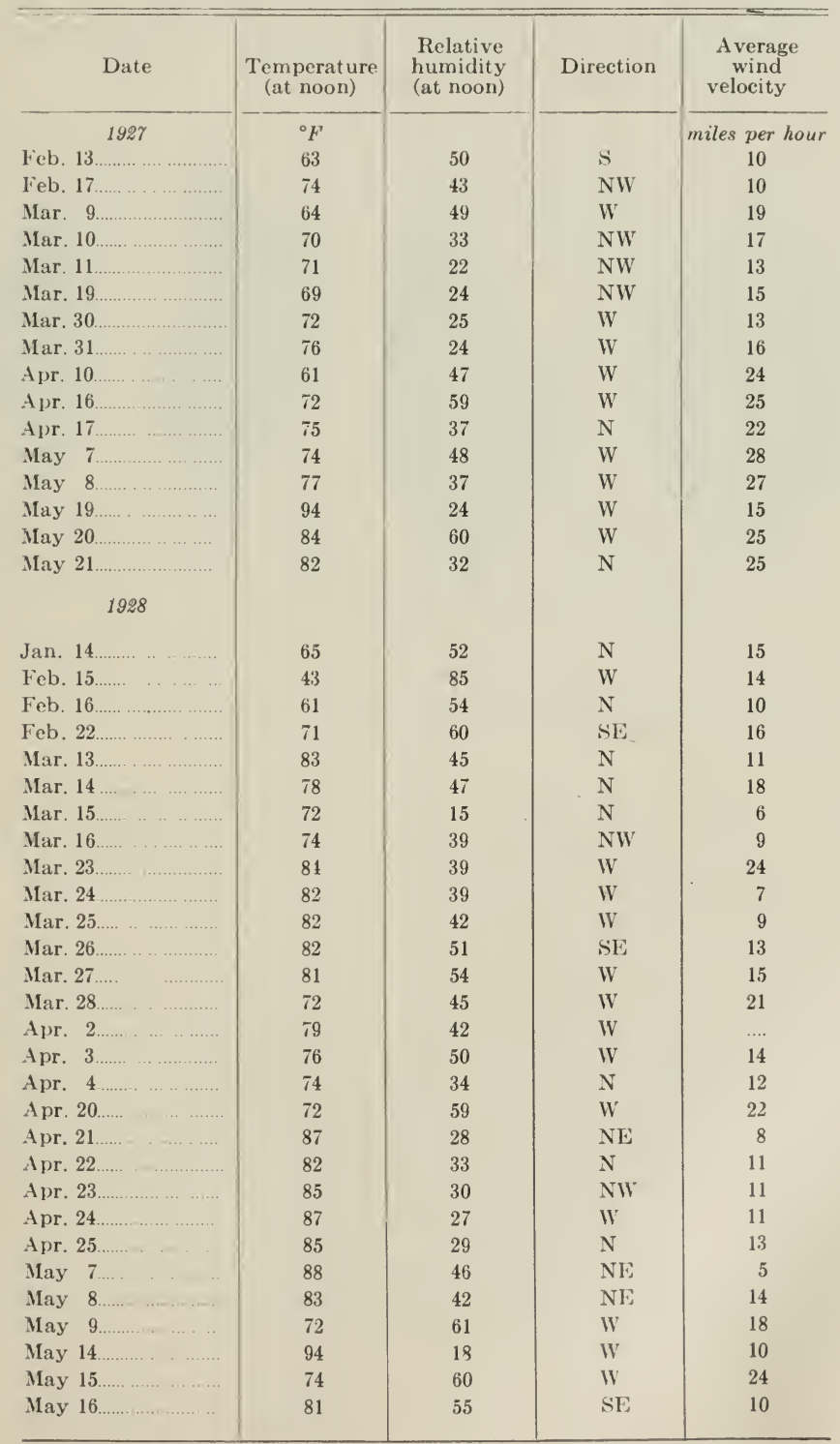

* From data obtained by Mr. J. W. Cook and furnished by Mr. James H. Gordon, meteorologist. 
In the absence of protecting windbreaks young grapefruit trees are often unsymmetrical in outline, owing to the retarded growth of shoots on the windward side. A certain amount of mutual protection exists when the trees reach mature size.

The effects of winds on the quantity and quality of grapefruit harvested is shown by a case reported to the authors by $\mathrm{Mr}$. F. G. Beyschlag, County Agent, in Imperial County. 'The D. M. Dorman grapefruit orchard contains 52 rows of trees. An athel (Tamarix
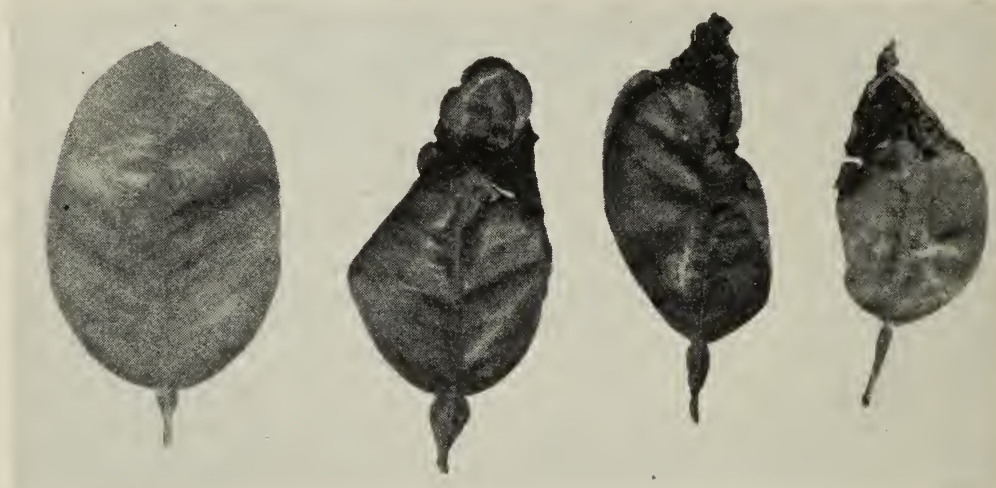

Fig. 15.- Young grapefruit leaves collected at Meloland, Imperial County, 17 days after a windstorm on March 22 and 23. The leaf at the left was not injured; the others show dead areas at the tips or margins.

articulata) windbreak along the west boundary protects 35 rows, leaving 17 rows unprotected. Many of the grapefruit trees in the first two rows adjacent to the windbreak had suffered from the root competition of the athel.

In 1927-28, when these trees were four years old, the yields from the west 15 trees in each row were measured and graded separately. The 525 trees protected by the windbreak produced an average of 1.15 boxes of fruit per tree, of which 70 per cent was Fancy, 27 per cent seconds, and 3 per cent culls. The 255 unprotected trees produced an average of 0.76 boxes of fruit per tree, of which only 57 per cent were Fancy, 37 per cent seconds, and 6 per cent culls.

According to this record the protected trees yielded 51 per cent more fruit and of much better quality, than the unprotected trees. 


\section{LABORATORY STUDIES OF VALENCIA ORANGE LEAVES IN RELATION TO WIND INJURY}

The conspicuous alterations in the external appearance of the citrus leaves produced by the northers have been mentioned, but these visible external alterations are preceded or accompanied by vital internal physiological changes. Some of these changes will be indicated under the different subheads in this section of the paper.

Water Contenl.-The data in table 11 will give an idea of the water content of both young and mature Valencia orange leaves under the climatic and other conditions to which these were subjected when

TABLE 11

Water Content of Valencia Orange Leaves

\begin{tabular}{|c|c|c|c|c|c|c|}
\hline \multirow[b]{2}{*}{ Age of leaves } & \multirow[b]{2}{*}{ Lot No. } & \multicolumn{2}{|c|}{ Weight of leaves } & \multicolumn{3}{|c|}{ Water content of leaves } \\
\hline & & Fresh & Dry & Weight & $\begin{array}{c}\text { Based } \\
\text { on fresh } \\
\text { weight }\end{array}$ & $\begin{array}{l}\text { Based } \\
\text { on dry } \\
\text { weight }\end{array}$ \\
\hline \multirow{6}{*}{ Young (1 cycle old). } & 1 & $\begin{array}{c}\text { grams } \\
298\end{array}$ & $\begin{array}{c}\text { grams } \\
81\end{array}$ & $\begin{array}{c}\text { grams } \\
217\end{array}$ & $\begin{array}{c}\text { per cent } \\
73\end{array}$ & $\begin{array}{c}\text { per cent } \\
268\end{array}$ \\
\hline & 2 & 170 & 45 & 125 & 74 & 278 \\
\hline & 3 & 151 & 51 & 100 & 66 & 196 \\
\hline & 4 & 264 & 87 & 177 & 67 & 204 \\
\hline & 5 & 173 & 56 & 117 & 68 & 209 \\
\hline & 6 & 192 & 62 & 130 & 68 & 210 \\
\hline \multirow{6}{*}{ Mature ( $2-3$ cycles old) } & $\tau$ & 313 & 133 & 180 & 58 & 135 \\
\hline & 8 & 225 & 96 & 129 & 57 & 134 \\
\hline & 9 & 240 & 102 & 138 & 58 & 135 \\
\hline & 10 & 275 & 120 & 155 & 57 & 129 \\
\hline & 11 & 220 & 94 & 126 & 57 & 134 \\
\hline & 12 & 155 & 67 & 88 & 57 & 131 \\
\hline
\end{tabular}

collected. Each lot of leaves was obtained from several trees and was taken from various branches on all sides of the trees. Lots 1 to 6 (young leaves) were taken from the same groups of trees respectively as were lots 7 to 12 (mature leaves). Lots 1, 2, 11, and 12 were taken from 13-year-old trees in the the Citrus Experiment Station grove at Riverside. Lots 1 and 11 were collected on October 27 and lots 2 and 12 on November 1, 1924. Lots 3 to 6 and 7 to 10 inclusive were taken from groves in Orange County on November 28, 1923. The leaves from Orange County were collected between 3:00 and $3: 30$ P.M. when there was a dry north wind blowing, a temperature of $70^{\circ} \mathrm{F}$, and a relative humidity of 19 . 
The data in table 11 show that there is a marked difference between the water contents of young and of mature leaves. The difference becomes especially noticeable when the dry weight of the leaves is made the basis for the determination of the percentage of water content. It is also noticeable that, with the exception of lots 1 and 2, the water content of the young and mature leaves respectively, from these different groves was similar. It should be borne in mind, however, that the water content of young or mature leaves taken from other groves, or even from these same groves under different growth, soil, and climatic condition, might differ widely from the results shown in table 11.

Cameron ${ }^{7}$ made monthly determinations of the water content of orange leaves from both vegetative and fruiting terminals. Expressed as percentage of fresh weight leaves from vegetative terminals showed a minimum of 57 per cent in February, a maximum of 75 per cent in June, and a yearly average of 68 per cent, while those from fruiting terminals showed a minimum of 58 per cent in March, a maximum of 66 per cent in September, and a vearly average of 60 per cent.

Leaf Transpiration.-In making field observations on orange-tree injury produced by the desiccating winds it was always noticed that the newly formed leaves were seldom injured. It seemed that this result might be at least partially caused by a difference in relative rates of tranpiration of new and old leaves. With this in mind the relative transpiring capacities of 90 mature and 80 young Valencia orange leaves were tested by the cobalt-chlorid method. While there are valid objections to the use of this method yet it proved to be sufficiently accurate for the purpose at hand.

Much variation was found in the rates at which leaves of a given age were capable of transpiring, but the results in general were such as to indicate that the mature ones may transpire more rapidly than young ones. The averages of the results of the tests on different days showed that mature leaves transpired $72,74,49,75$, and 64 per cent while at the same time the young leaves transpired only $58,62,36,44$, and 59 per cent, respectively, of the amount evaporated by the moist surface used as a standard.

The comparative rates of transpiration of young and mature leaves were tested in another manner. A piece of glass tubing $7 \frac{1}{2}$ centimeters long and $3 \mathrm{~cm}$ in diameter was sealed to each surface of a given leaf. Into each of these tubes was inserted a small wire-gauze basket of weighed, 8-mesh calcium chlorid and the tubes closed. At the end of 20 to 21 hours the baskets were removed and reweighed to

7 Cameron, S. H. Unpublished data. 
determine the amount of water that had been absorbed from the leaf by the calcium chlorid. The leaves tested were from three different cycles of growth and were approximately 3, 6, and 12 months old. The average amounts of water absorbed by the calcium chlorid from each set of leaves were 81, 90, and 119 grams respectively; or in other words, the leaves 3 months old gave off 68 per cent and the leaves 6 months old gave off 76 per cent as much as the leaves that were 12 months old.

Effect of Spray Materials on Transpiration.-On the same dates that the cobalt-chlorid tests were made, mature Valencia orange leaves that had been previously sprayed with lime or with petroleum oil were also tested in the same manner, their observed rates of transpiration being compared with those of similar unsprayed leaves. Tests were made at intervals of $11,12,21,31$, and 47 days after the application of the sprays. The lime spray produced rather a marked increase in the observed rate of transpiration. The rate increased 12 to 26 per cent over that of the similar unsprayed leaves. The application of the oil spray appeared to produce an initial decrease but later an increase in the possible rate of transpiration. For example, the tests made 11 and 12 days after the spray had been applied showed reductions of 2 per cent and 5 per cent respectively in the rate of transpiration, but the tests made 31 and 47 days after the application showed increases of 19 per cent and 15 per cent respectively. These results agree with data obtained by Knight, Chamberlain, and Samuels (1929). They found that the application of a 2 per cent quick-breaking emulsion of light oil caused a depression in the rate of transpiration for 1 or 2 weeks, after which the rate became excessive for a time and then went back to normal. When they used heavy oils the depression period lasted from six to eight weeks.

Loss of Water During Artificial Wilting.-It is well known, of course, that under certain conditions the leaves of many kinds of trees may show a marked wilting; the citrus tree is no exception. This is brought about by variations in leaf structure, the nature and amounts of substances in the leaf, and by environmental conditions. To determine the difference in the water content of a given lot of leaves in a turgid and then in a wilted condition, mature leaves were brought to the laboratory, weighed, allowed to remain in a current of air until wilted, then reweighed, and dried to constant weight in an oven at $70^{\circ} \mathrm{C}$. The results of this test are shown in table 12 . The leaves in lots 1 and 2 were taken from 13-year-old trees that had not been irrigated since August 6 (periods of 55 and 110 days, respectively). The leaves in lots 3 and 4 were taken from trees in an adjacent portion 
of the same grove in which the water content of the soil had been well maintained because of frequent irrigations required by the young crop of Melilotus. Determinations made on November 24 show a significant difference between the two plots. The difference was most conspicuous in the zone occupied by the roots.

TABLE 12

Water Loss from Mature Valencia Orange Leaves During Wilting

\begin{tabular}{|c|c|c|c|c|c|c|c|c|c|}
\hline \multirow{3}{*}{$\begin{array}{l}\text { Iot } \\
\text { No. }\end{array}$} & \multirow{3}{*}{$\begin{array}{l}\text { Date, } \\
1924\end{array}$} & \multicolumn{3}{|c|}{ Depth, feet } & \multicolumn{3}{|c|}{ Weight of leaves } & \multicolumn{2}{|c|}{$\begin{array}{l}\text { Loss of water during } \\
\text { wilting }\end{array}$} \\
\hline & & 0 to 1 & 1 to 2 & 2 to 3 & \multirow[b]{2}{*}{$\begin{array}{l}\text { Fresh, } \\
\text { grams }\end{array}$} & \multirow[b]{2}{*}{$\begin{array}{l}\text { Wilted, } \\
\text { grams }\end{array}$} & \multirow[b]{2}{*}{$\begin{array}{c}\text { Dry, } \\
\text { grams }\end{array}$} & \multirow[b]{2}{*}{$\begin{array}{l}\text { Per cent of } \\
\text { fresh weight }\end{array}$} & \multirow[b]{2}{*}{$\begin{array}{l}\text { Per cent of } \\
\text { dry weight }\end{array}$} \\
\hline & & \multicolumn{3}{|c|}{$\begin{array}{l}\text { Moisture in soil expressed as } \\
\text { ratio of wilting } \\
\text { coefficient }(=1)\end{array}$} & & & & & \\
\hline 1 & Sept. 30 & & & & 174 & 150 & 76 & 13 & 32 \\
\hline 2 & Nov. 24 & 0.73 & 0.70 & 0.97 & 56 & 53 & 23 & 5 & 14 \\
\hline 3 & Sept. 30 & & & & 145 & 128 & 62 & 11 & 26 \\
\hline 4 & Nov. 24 & 1.75 & 1.33 & 098 & 98 & 88 & 40 & 10 & 25 \\
\hline
\end{tabular}

Leaves may begin to wilt, of course, before they have lost as much water as is indicated in table 12 , but these results indicate, in a general way what percentage of water may be lost by mature Valencia leaves during the process of marked artificial wilting in the laboratory and similar wilting in the grove as the result of a norther or the lack of moisture in the soil. The last is indicated by the fact that during wilting the leaves in lot 2 lost only 14 per cent of their dry weight while those in lot 4 lost 25 per cent, the former being from the trees that had not been irrigated for 110 days and the latter from trees having received frequent and regular irrigations. The leaves in lot 4 from trees in the irrigated plot might be said to have a greater margin of safety than those in lot 2 from trees in the dry plot. Although it is not possible to wilt different lots of leaves artificially to exactly the same point, it should be borne in mind that the leaves in lots 2 and 4 were exposed to the current of air at the same time during the process of wilting. The same may be said of lots 1 and 3 . In this connection it is of interest to note that Koketsu (1928), in working with plants other than citrus, found that although the water content of the leaves at the critical wilting point varied with different kinds of plants, yet the water content of these leaves at full turgidity, slight wilting, and permanent wilting appeared to be approximately constant in each stage. Koketsu suggests therefore that the leaves of a plant contain a constant amount of water corresponding to the stage of 
wilting, and that the ratio of the water content at the wilting point to that at full turgidity, might indicate the degree of xerophytism of the plant.

The comparative rates at which young and mature Valencia orange leaves may lose water is shown in figure 16 . The petioles were removed from 10 young and 10 mature leaves and the scars sealed with

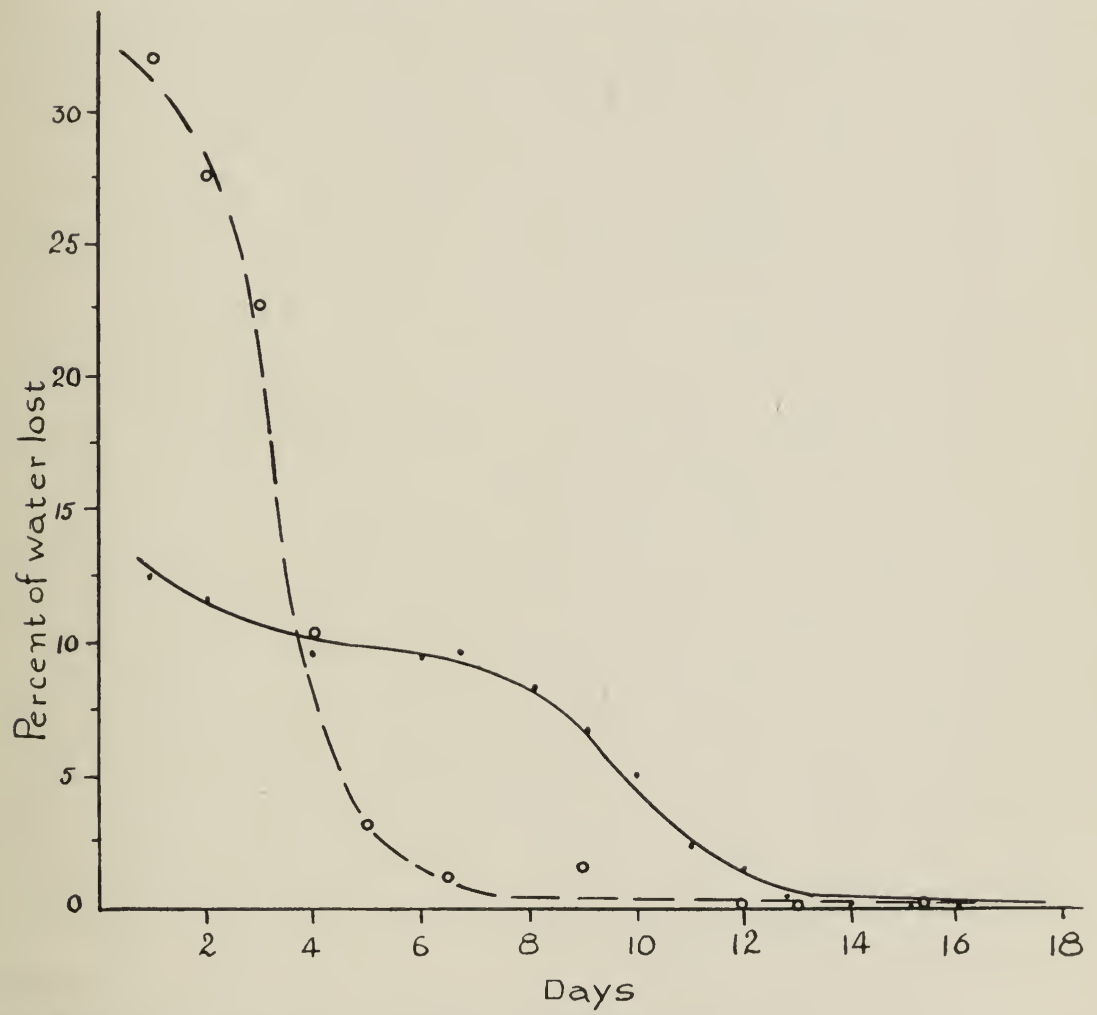

Fig. 16.-Daily water losses from detached orange leaves in a desiccator. The solid line represents losses from young leaves, the broken line, losses from mature leaves.

wax. The leaves were then weighed, placed in a desiccator over sulfuric acid, and reweighed at intervals as indicated in the figure. The figures given on the ordinate represent percentages of the total amounts of water lost. The leaves were collected in October.

The graphs in figure 16 show that the mature leaves lost water much more rapidly and constantly than the young ones. By the end of the seventh day the mature leaves had lost practically all of their water, while it took 13 days for the young leaves to lose a like proportion. Based on fresh weight the total loss of water from the mature 
leaves was 54.7 per cent and from the young ones 73.4 per cent; based oll dry weight the mature ones lost 122.4 per cent and the young ones 275.6 per cent.

Rate of Water Loss from Ventral and Dorsal Surfaces.-To obtain further data on the rates at which they may lose water under artificial conditions, mature Valencia orange leaves were divided into three equal lots. In one they had their dorsal (upper) side covered with wax, in the second the ventral (under) side covered, and in the third neither side was covered. The petioles of all leaves were dipped in melted wax. The wax was composed of beeswax, resin, tallow, and olive oil in such proportions that the mixture would adhere firmly to the leaf surface, and also have such a low melting point that the leaves would not be injured during its application. In two of the tests the finger was used to spread the wax and in the other two the wax was heated a little more and applied with a broad camel's-hair brush. The two methods appeared to give the same results. The leaves were placed in wire baskets in such a manner that the surfaces of no two leaves touched each other. In one test 18 leaves were placed in each of three baskets and all baskets were placed in the same desiccator. In the other three tests 12 leaves were placed in each basket and the baskets were placed in separate desiccators, all of which were of equal size and contained the same amounts of calcium chlorid. The desiccators were kept in a dark room at a temperature of $68^{\circ}$ to $70^{\circ} \mathrm{F}$. The only apparent difference in the results of the two methods was that the lots of leaves placed in separate desiccators lost water more rapidly than when all three lots were placed in the same desiccator. The end results were similar. Since the end results of all of the tests were similar only those for one test are given, and they are shown in the graphs in figure 17.

The weighings in this test were continued for 15 days, at which time the weights became practically constant. The graphs in figure 17 show only the first six weighings. The total loss of water from the leaves that were not coated was 133.21 per cent, from those coated on the dorsal side 127.20 per cent, and from those coated on the ventral side 125.18 per cent of the dry weight of the leaves.

In view of the fact that the dorsal surface of the orange leaf contains no stomata, it is remarkable that as much water should escape through the upper, cutinized epidermis as is shown by these results.

It is probable that the application of a coating of wax to one surface of these leaves enhanced the escape of water from the other surface. The rate of water loss from a given side during the 6-day period may, therefore, be somewhat exaggerated in the case of the waxed 
leaves, but since each lot was affected in a similar way, the general conclusion stated in the preceding paragraph is not invalidated

Concentration of Soluble Solids in Young and Mature Leaves, and Viscosity of the Expressed Sap.-The concentration of solids and viscosity of expressed sap of orange leaves was determined with

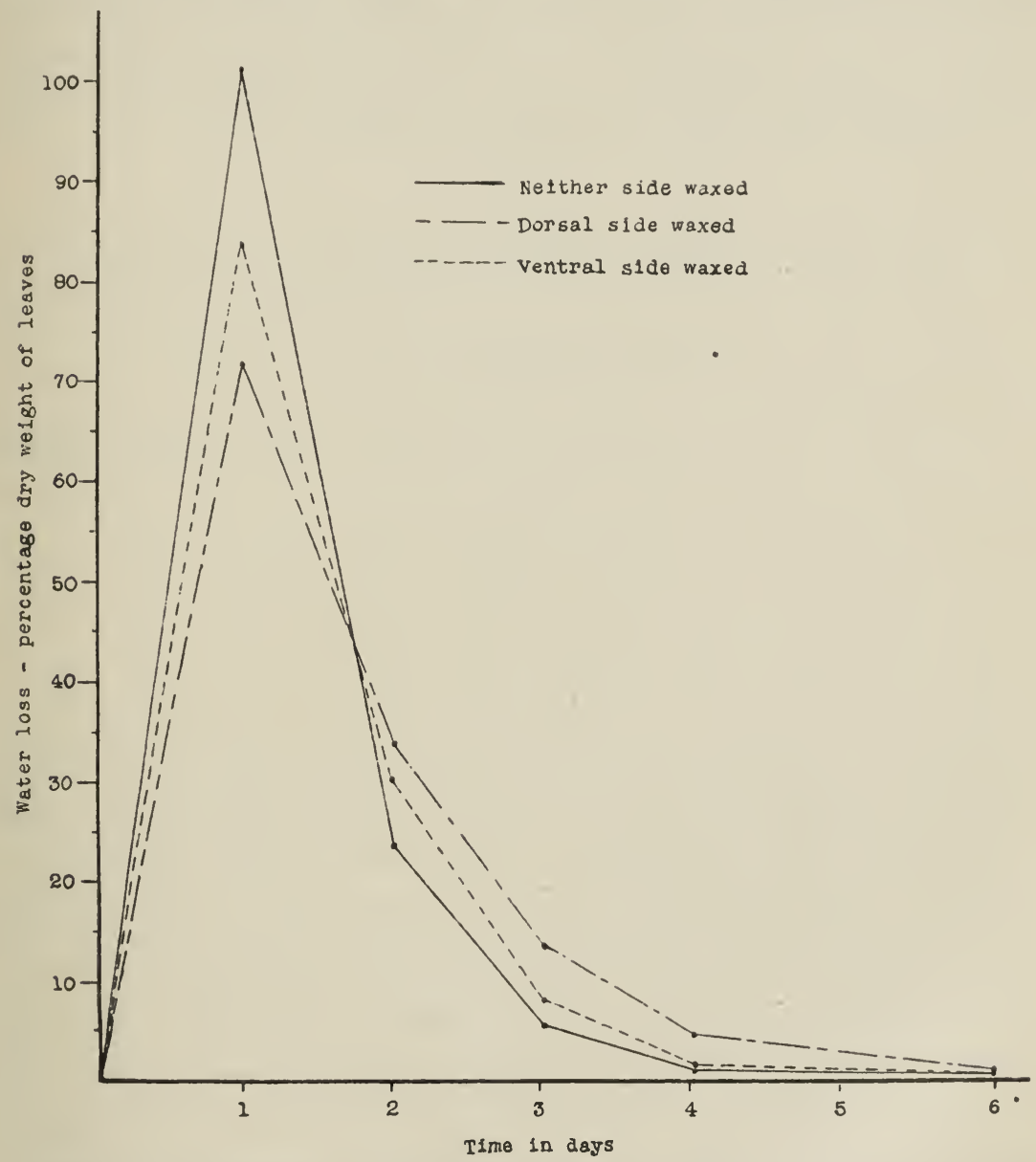

Fig. 17.-Comparative rates of water loss from three lots of mature Valencia orange leaves, one lot having the dorsal, one the ventral, and the other having neither side coated with wax.

reference to two extrinsic factors, viz., age of leaf and soil moisture at the time of taking the sample. The samples were taken from four groves in which the soil moisture conditions to a depth of 3 feet varied as shown in table 13. Meteorological conditions at the time of taking the samples also varied, but none of them represented actual norther conditions. 
'The leaves selected for study were frozen and finely ground and the sap extracted by pressure. Approximately 300 grams of leaves were used in each test. The concentration of soluble solids was determined by the use of an Abbe refractometer and the viscosity by an Oswald viscosimeter. All readings of both the refractometer and the viscosimeter were taken at a controlled temperature of $25^{\circ} \mathrm{C}$. The viscosity readings show the ratio between the viscosity of the leaf sap and that of distilled water, the latter being considered as 100 . The results of these tests are recorded in table 13.

TABLE 13

Concentration and Viscosity of Sap Expresssed from Young and Mature Valencia Orange Leaves

\begin{tabular}{|c|c|c|c|c|c|c|c|c|}
\hline \multirow{3}{*}{ Grove } & \multirow{3}{*}{ Date collected } & \multirow{2}{*}{\multicolumn{3}{|c|}{$\begin{array}{c}\begin{array}{c}\text { Moisture in soil expressed as } \\
\text { ratie of wilting coefficient }(=1)\end{array} \\
\text { Depth }\end{array}$}} & \multicolumn{4}{|c|}{$\begin{array}{c}\text { Character of sap from mature and young } \\
\text { leaves }\end{array}$} \\
\hline & & & & & \multirow{2}{*}{$\begin{array}{l}\text { Mature, } \\
\text { per cent }\end{array}$} & \multirow{2}{*}{$\begin{array}{l}\text { Young, } \\
\text { solids }\end{array}$} & \multirow{2}{*}{$\begin{array}{c}\text { Mature } \\
\text { viscosity }\end{array}$} & \multirow{2}{*}{$\begin{array}{c}\text { Young, } \\
\text { (distilled } \\
\text { water }=100 \text { ) }\end{array}$} \\
\hline & & $\begin{array}{l}\text { First } \\
\text { foot }\end{array}$ & $\begin{array}{l}\text { Second } \\
\text { foot }\end{array}$ & $\begin{array}{l}\text { Third } \\
\text { foot }\end{array}$ & & & & \\
\hline 1 & Oct. 12,1923 & 0.89 & 0.76 & 0.82 & 26.7 & 16.4 & 465 & 153 \\
\hline 1 & Oct. 31,1923 & 1.16 & 0.84 & 0.70 & 27.4 & 17.8 & 335 & 158 \\
\hline 2 & Oct. 12,1923 & 1.00 & 0.91 & 0.89 & 27.2 & 16.0 & 572 & 155 \\
\hline 2 & Oct. 26,1923 & 1.37 & 1.09 & 1.07 & 26.7 & 17.5 & 789 & 172 \\
\hline 3 & Oct. 12,1923 & 0.95 & 0.88 & 0.77 & 28.8 & & 440 & \\
\hline 4 & Oct. 10,1924 & 0.53 & 0.57 & 0.92 & 30.3 & & 970 & \\
\hline 4 & Oct. 13,1924 & 0.80 & 0.67 & 0.61 & 30.5 & & 785 & \\
\hline
\end{tabular}

The viscosity is influenced principally by the organic substances in solution in the sap such as the colloids, while the percentage of solids is governed by the inorganic as well as the organic substances in solution. The results of the viscosity tests as given in table 13 show that the sap from the mature leaves was markedly more viscous than that from the young ones. The refractometer readings show that in these different lots of leaves the percentage of soluble solids was almost twice as great in the sap from the mature leaves as in that from the young ones. The results also show that in a general way the percentage of soluble solids in the sap may be directly influenced by the amount of available moisture in the soil. For example, the two lowest soil moisture contents were found in grove 4, and the percentages of soluble solids in the sap in mature leaves from this grove were appreciably higher than those from any of the other groves.

The figures in table 13 do not of course indicate the total amount of soluble solids or of the substances affecting viscosity that were contained in the leaves. 'They indicate only the comparative amounts of 
these substances that could be obtained by a single application of like pressure to each sample of leaf 'meal.' To determine the relative amounts of these substances that could be obtained by successive additions of water and applications of pressure, the following test was made. Six hundred and seven grams of mature leaves were frozen, finely ground, and pressed, yielding $73 \mathrm{cc}$ of sap. The cake of leaf meal was then thoroughly wet with 73 ec of distilled water and again pressed. This process was repeated several times, with the results shown in table 14. The first readings are those of the original sap.

TABLE 14

Successive Extractions of Soluble Solids and Substances Affecting Viscosity, from a Single Lot of Mature Valencia Orange Leaves

\begin{tabular}{c|c|c}
$\begin{array}{c}\text { Extrac- } \\
\text { tion }\end{array}$ & $\begin{array}{c}\text { Per cent } \\
\text { soluble solids } \\
\text { (refractometer } \\
\text { readings) }\end{array}$ & $\begin{array}{c}\text { Viscosity } \\
\text { (water=100) }\end{array}$ \\
\cline { 1 - 1 } 1 & 35.10 & 1,875 \\
2 & 15.25 & 157 \\
3 & 12.65 & 148 \\
4 & 10.00 & 128 \\
5 & 7.80 & $\ldots \ldots$ \\
6 & 5.70 & 105 \\
7 & 4.80 & $\ldots \ldots$. \\
\hline
\end{tabular}

The findings of Haas and Reed (1927) may be cited as further evidence that the percentage of soluble or total solids in the leaf sap may be governed at least to some extent by the amount of available moisture in the soil. They reported that the total ash in Valencia orange leaves on July 29, following several weeks of dry, hot weather, amounted to 15.52 per cent of the dry weight of the leaves. Basins were then made around the trees and filled 3 inches deep with water. The resulting increase in the amount of water in the tree tissues permitted a portion of the salts 10 migrate from the leaves, where they had excessively accumulated during the dry period, back into the branches, so that 2 days after the application of the water the percentage of ash in the leaves had decreased from 15.52 to 14.39 per cent. Two subsequent samples showed very little change.

The work of Haas and Reed further shows, however, that climatic conditions may be a more potent factor than the moisture content of the soils in governing the accumulation of salts in the leaves. Two lots of leaves were collected from Valencia orange trees immediately after a 3-day period of desiccating wind. One lot of leaves had been killed so quickly that there was little chance for the accumulation of salts; the other lot, from the same trees, had wilted during the wind 
period but regained their turgidity when the wind ceased to blow. A third lot of leaves was collected from these trees 10 days after the wind had ceased to blow. These leaves, like those in the second lot, had been wilted but were not injured by the wind. The moisture content of the soil in which the trees were growing was well above the wilting point both during and after the windy period. The trees had been previously fertilized with calcium nitrate. The three lots of leaves were analyzed to determine their comparative contents of both water-soluble and insoluble solids. The results are given in table 15, which is taken from the article by Haas and Reed.

\section{TABLE 15}

The Effect of Desiccating Winds on the Ash Content of Mature Valencia Orange Leaves; Results Expressed as Percentage of Dry Matter*

\begin{tabular}{|c|c|c|c|c|c|c|c|}
\hline \multirow{3}{*}{ Date of collections } & \multicolumn{2}{|c|}{ December 12,1924} & \multirow{3}{*}{$\begin{array}{c}\begin{array}{c}\text { Dec. 22, } \\
1924\end{array} \\
\text { Uninjured }\end{array}$} & \multirow{2}{*}{\multicolumn{2}{|c|}{$\frac{\text { December } 12,1924}{\text { Injured }}$}} & \multirow{2}{*}{\multicolumn{2}{|c|}{$\frac{\text { December } 12,1924}{\text { Uninjured }}$}} \\
\hline & \multirow[b]{2}{*}{ Injured } & \multirow[b]{2}{*}{ Uninjured } & & & & & \\
\hline & & & & $\begin{array}{c}\text { Water in- } \\
\text { soluble }\end{array}$ & $\begin{array}{l}\text { Water } \\
\text { soluble }\end{array}$ & $\begin{array}{l}\text { Water in- } \\
\text { soluble }\end{array}$ & $\begin{array}{l}\text { Water } \\
\text { soluble }\end{array}$ \\
\hline Ash 1 & $\stackrel{2}{14.10}$ & 17.03 & $14^{4} 58$ & $\begin{array}{ll} & 5 \\
6 & 10\end{array}$ & $\begin{array}{c}6 \\
811\end{array}$ & $\begin{array}{c}7 \\
6 \quad 26\end{array}$ & $\begin{array}{c}8 \\
10.31\end{array}$ \\
\hline Ash constituents: & & & & & & & \\
\hline $\mathrm{Na}$ & 0.14 & 0.14 & 0.18 & & 016 & 003 & 0.18 \\
\hline $\mathrm{K}$. & 060 & 0.50 & 0.60 & 004 & 068 & 002 & 0.53 \\
\hline $\mathrm{Ca}$. & 451 & 576 & 483 & 2.08 & 2.39 & 226 & 3.26 \\
\hline $\mathrm{Mg}$ & 0.40 & 0.42 & 0.38 & 008 & 031 & 008 & 0.40 \\
\hline $\mathrm{Cl} \ldots$ & 003 & 0.04 & & Trace & 003 & Trace & 0.04 \\
\hline $\mathrm{SO}_{4}$ & 0.40 & 033 & 0.30 & 0.09 & 026 & 005 & 0.26 \\
\hline $\mathrm{PO}_{4}$ & 0.61 & 0.56 & 054 & $\begin{array}{lll}0 & 15\end{array}$ & $0 \quad 32$ & 016 & 043 \\
\hline
\end{tabular}

${ }^{*}$ From: Haas, A. R. C., and H. S. Reed. Relation of desiccating winds to fluctuation in ash content of citrus leaves and phenomenon of mottle leaf. Bot. Gaz. 83: 161-172. 1927.

\section{Effect of Excessive Transpiration on Coagulation of Leaf Sap.-} The relation of desiccation to scorch is not understood, although it is probable that the two are causally connected. The following experiments show that the coagulation characteristic of scorch occur's more readily in sap from leaves which have suffered from excessive transpiration. After a period of desiccating wind, leaf sap was obtained from a grove that had shown little, if any, damage. When this sap was subjected to a temperature of $40^{\circ} \mathrm{C}\left(104^{\circ} \mathrm{F}\right)$ it took 25 minutes to coagulate it. At $50^{\circ} \mathrm{C}\left(122^{\circ} \mathrm{F}\right)$ it took 5 minutes. Leaf sap obtained from a near-by grove that had shown severe injury coagulated in 5 minutes and 1 minute respectively when subjected to the same temperatures. The leaf sap from trees in a third grove which had shown windburn injury and in which the soil moisture content was considerable below the wilting point, coagulated in 2 minutes when subjected to a temperature of $48^{\circ} \mathrm{C}\left(118^{\circ} \mathrm{F}\right)$. 
Sugar Content of Joung and of Mature Leaves.-Many workers have made guantitative determinations of both organic and inorganic substances in various citrus fruits. but so far as can be found in the literature, very little has been done in the way of making quantitative determination of organic substances in the leaves. What work has been done has been confined largely to their oil contents. Cameron (1927) has made carbohychate determinations on citrus leaves but his detailed results have not yet been published. In the report referred to he states that "free reducing substances and sucrose are very low in amount and remain nearly constant." During the course of the study of wind injury to orange trees rather limited determinations were made on the sugar content of both mature and young Valencia orange leaves. The leaves were taken from, at least eight different trees and from all sides of the trees. Each lot consisted of about 300 grams.

TABIL 16

Sugar Content of Valexcia Orange Leaves; Percentages Based on Dry WeIGHT OF LEAVES

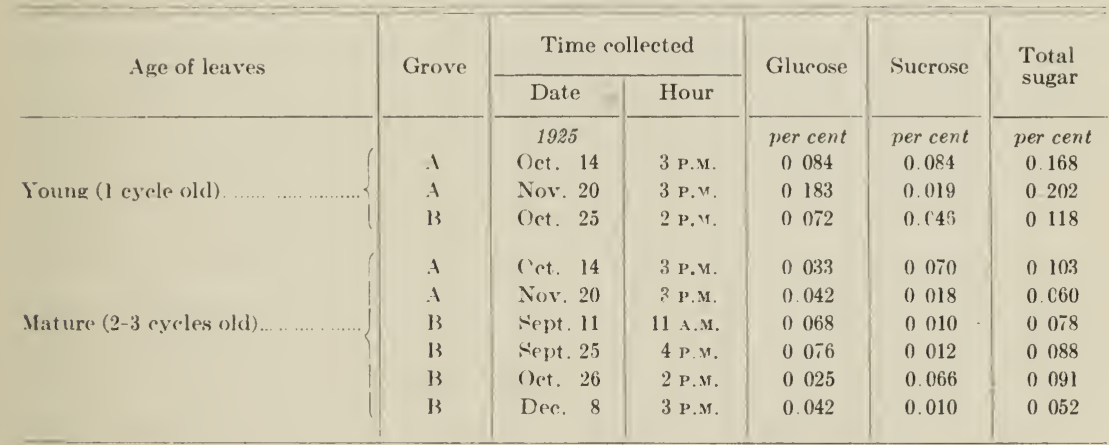

Some of the lots were collected at a considerable distance from the laboratory so they could not be tested at once. In such cases each lot was put into a tight container and several cubic centimeters of chloroform were added at once to inhibit the progress of chemical changes in the leaves. As soon as the leaves could be brought to the laboratory they were removed from the containers and dried at a temperature of $70^{\circ} \mathrm{C}\left(158^{\circ} \mathrm{F}\right)$. The leaves were then finely ground and the powder thoroughly mixed. Samples of the leaf powder were extracted with distilled water at a temperature of $80^{\circ} \mathrm{C}\left(176^{\circ} \mathrm{F}\right)$ until no more sugar could be extracted. Calcium carbonate was added to the filtrate to neutralize any acid that might be present. All extraction filtrates from a given sample were combined and made up to a given volume. Aliquots were then tested for glucose and 
sucrose. In testing for the latter, 5 ec of concentrated hydrochloric acid were added to each 50 ce aliquot of the filtrate and heated for 10 minutes in a water bath at $70^{\circ} \mathrm{C}\left(158^{\circ} \mathrm{F}\right)$. The sugar determinations were made by the sodium-thiosulfate titration method described by Spoehr (1919). The results of these tests are shown in table 16 . The percentages given in this table are based on the dry weight of the leaves.

The figures in table 16 indicate that Valencia orange leaves, at least at the time of the year and for the conditions under which they were tested, contain a comparatively small amount of sugar. The young leaves contained appreciably higher percentages of sugar than the mature ones. With the exceptions of the young leaves from grove $A$ on October 14, and the mature ones from grove $A$ on October 14 and grove $B$ on October 26 , the amounts of glucose in the leaves considerably exceeded the amounts of suerose.

Plasmolysis and Gum Deposits in Leoves and Twigs.-Portions of leaves that showed the mottled effect and of those that had turner? brown, together with their petioles, were fixed, imbedded, sectioned, stained, and studied under the microscope. It was found that in the green portions of the leaf the cells appeared to be in a healthy condition, while in the mottled areas and in the brown leaves the cells were in varying stages of plasmolysis, depending upon the degree of injury.

In the water-conducting vessels of the lower portion of the midrib of the brown leaves and in their petioles, deposits of gum were found. Some of the vessels contained little or no gum but many were completely clogged by it. $\chi$ Gum was found not only in these vessels but also in the vessels of the twig to which the injured leaves were attached. Twigs collected 16 days after the leaves had been turned brown by the desiccating wind, while they were still attached to the twigs, showed gum in the vessels several inches below the point at which the lowest injured leaf had been attached. Twigs of this sort died not only in that portion that bore the brown leaves but often several inches below the point of attachment of the lowest injured leaf. In contrast to this the twigs that had been defoliated by windburn showed no gum in the vessels, remained alive, and later put out new leaves.

It was further observed that, as a rule, if the scorched, brown leaves were mechanically removed from the twigs by a second hard wind, there occurred little, if any, discoloration in the bark or gumming in the wood and injury to the twigs was at a minimum. It was usually not sufficient to kill them. 
Discussion.-The citrus leaf may lose a comparatively large percentage of its water content in a short time, during periods of stress, and not be permanently injured, provided the loss is replenished at the end of the period. Table 12 shows that Valencia orange leaves lost from 14 per cent to 32 per cent of their water content during wilting. While these results were obtained under artificial conditions, it may well be that similar amounts are lost from the leaves while attached to the tree. It seems probable that the loss of a greater percentage of water from one lot of leaves than from another, during wilting, may have been at least partially due to differences in. the water content of the leaves at the time they were collected. For example, in the case of lot 2 , table 12 , where the loss was only 14 per cent, the leaves were collected after 2 days of desiccating winds, November 23 and 24.

The results of the tests on the comparative rates of transpiration of young and mature leaves indicate that the reason the former are not as badly burned as the latter rests not only in the fact that they contain a considerably higher water content (see table 11) but that they are better able to conserve it. The fact that they are better able to conserve it is shown by the results of both the cobalt chlorid and the calcium chlorid tests, in which many leaves were tested individually, and by the desiccator method, in which the leaves were tested en masse. For the results obtained by the last method, see figure 16 .

It is not a difficult matter to prove that the younger the leaf the greater the water content. To the proofs offered in this paper may be added the results obtained by Hodgson (1917) who found that leaves 2 weeks old contained 242 per cent, leaves of the current season 162 per cent, leaves 1 year old 133 per cent, 2 years old 126 per cent, and over 2 years old 118 per cent of their dry weights. Similar results were obtained by Kelley and Cummins (1920). They found that. based on fresh weight, Valencia orange leaves 1 week, 6 weeks, 6 months to 2 years, and 3 or more years of age contained, respectively, 73 per cent, 69 per cent, 61 per cent, and 59 per cent water. But just what enables the younger leaves to be more efficient than the mature ones in retaining their water is more difficult to determine. The results obtained by different workers indicate that it may be a combination of factors.

As a result of their study of the burning of orange foliage by the autumn siroces, Boeuf and Genet (1906) suggest that one reason that mature leaves are much more severely injured than young ones rests in the fact that the mesophyll in the former is proportionately more abundant than in the latter. This condition would permit more rapid 
transpiration because of more favorable conditions for the diffusion of water vapor.

Coit and Hodgson (1919) found that the stomata of the citrus leaf tend to lose their regulatory power as the leaf becomes older. Hence it is probable that the young leaves are less easily injured by the desiccating winds because their stomata can function, thus conserving the water content of the leaf by reducing transpiration. These writers point out, however, that much of the transpirational water may be given off through the cutinized epidermis, regardless of the presence or absence of stomata. They found, for example, that as much as 25 per cent of the transpiration of young leaves and 40 to 50 per cent of that of mature ones may occur through the upper epidermis in which there are no stomata. The results shown by the graphs in figure 18, together with preliminary unpublished data obtained by the writers, indicate that even these figures may be too low.

The preceding statements indicate that the citrus leaf is not a very efficient organ for the conservation of its moisture. Shreve (1913) has found that the loss of functioning power of the stomata as they grow older and a comparatively high rate of cuticular transpiration are characteristics of rain-forest and shade-loving plants. Coit and Hodgson have pointed out that in the light of this work by Shreve and by others it seems probable that the citrus tree is of rain-forest origin, which, if true, helps to explain its comparative inefficiency in water conservation.

The wind-scorched, mature leaves may be injured only in restricted areas, as indicated in figure 13, or the entire leaf may be killed. The histological study of these leaves showed that the injured areas were in various states of plasmolysis. This condition lends support to the suggestion of Haas and Reed (1927) that the desiceating winds may bring about a cogulation of the proteins to such an extent that the leaf or certain portions of it may be killed.

In this connection Blackman's (1909) discussion of the work of Lidforss, Gorke, and others, is of interest. In these discussions the phenomenon of 'salting-out' of the proteins, due to the increased concentration of salts in the cell sap, is presented as an explanation for the killing of tissues subjected to freezing temperatures.

In the one case the desiccation and the resulting increase in salt concentration is produced as a result of freezing, while in the other it is produced by excessive transpiration, but it seems possible that either might cause a 'salting-out' of the proteins. 'That a marked increase in concentration of salts in the cell sap of the leaves is caused by the desiccating winds is shown by the results given in table 15 . Whether 
this increase in the percentage of ash in the orange leaves is real or is merely a matter of computation might be questioned. The excessive respiration during a windstorm might so deplete the stores of carbohydrates that the ash, expressed as a percentage of dry weight, would show an increase. This explanation does not seem to be correct because the concentration of cell sap (determined by the freezing-point depression or by the refractometer) showed no such decrease as would be expected on that basis. Moreover, if it is merely a case of loss in dry weight due to excessive respiration, one would expect the change in percentage of ash to be manifest in the insoluble, as well as watersoluble, constituents of the ash as given in table 15 . However, a comparison of the values in columns 5 and 7 in the table shows no such increase as would be expected on this basis, because the differences are so small as to lack significance.

That injury to the leaves, from which a large amount of water has been withdrawn, resulting in an excessive accumulation of salts, may be at least partially due to coagulation or precipitation of certain of the cell contents, does not seem impossible for still another reason. Since a temperature of $40^{\circ} \mathrm{C}\left(104^{\circ} \mathrm{F}\right)$ produces a coagulation and precipitation in a given extracted sap in 5 minutes, it does not appear altogether improbable that, within certain limits, a lower temperature might produce similar results within the leaf if the time period were extended. In this connection it should be remembered that the excessive transpiration which occurs during the early stages of wind injury tends to keep the interior of the leaves cool, but as soon as the rate of transpiration begins to fall then there is a proportionate rise in temperature in their interior. This may have a bearing upon the coagulation or precipitation of the contents of the cells, especially in the presence of excessively accumulated salts.

The data in table 16 which show that the sugar content of the young leaves was more than twice that of the mature ones afford further support of the writers' ideas of the reason that young orange leaves escape injury from the winds. While the addition or accumulation of salts may cause a salting-out of the proteins, the presence of a non-electrolyte, such as sugar, may retard or even entirely prevent this salting-out effect. Therefore it seems logical to conclude that the presence of more than twice as much sugar in the young leaves as in the mature ones may have been one of the factors which prevented the young ones from being injured.

As a result of his study of the physiology of apple-leaf scorch caused by desiccating winds, Summers (1923) offers an explanation which may help to explain the effects of similar winds on citrus leaves. 
He states that as a result of the drying out of the leaf, respiration is accelerated. This causes the quantity of chromogen or color-bearing bodies to be greatly increased. If the leaf is dried very quickly the oxidizing enzymes which act upon these chromogens cannot function and the leaf, though dried out, remains green. If, however, the leaf dries more slowly the oxidizing enzymes may turn the leaf brown while it is drying. Summers found also that the leaf which dried quickly and remained green, might later turn brown provided sufficient moisture were absorbed to permit the oxidizing enzymes to act before they were destroyed.

The greater the viscosity of the cell sap the greater the tenacity with which it will hold water, but this does not seem to have been an important factor in governing the extent of leaf injury. The total average viscosity (table 13 ) of the young leaves was only 29 per cent of that of the mature ones, and yet the mature leaves which had the high sap viscosity were the ones that were injured.

Bernberk (1920) expressed the view that plants give off excessive amounts of water during wind storms because bending strains and stresses are produced in different portions of the plant. These, he says, mechanically force the water from the interior of the cells and from the cell walls into the intercellular spaces and even out through the epidermis. Although this may account for a certain amount of water loss from the stems and leaf petioles, it seems that his explanation could apply only indirectly to a leaf as rigid as that of citrus. This is especially true when it is considered that the blade of the mature leaf is much more rigid than that of the young one, and yet it is the former which is injured by the wind storms.

In a histological study of the mature, partially injured citrus leaves it was found that the cells in the injured areas were plasmolyzed while the adjoining cells appeared to be in a healthy condition. In the leaves which were entirely killed all cells were plasmolyzed. If the severely injured leaves remained attached to the twigs for several days gum was formed in the petioles and twigs. Just what eaused this gum to form is not entirely clear. It was noted that the phloem portion of the bundle turned dark brown to almost black and that this discoloration extended into the phloem in the bark of the healthy portion of the twig a short distance below the point of attachment of the lowest injured leaf. This discoloration was probably due to the action of an oxidizing enzyme. This action may have produced toxic substances which stimulated gum formation, but this explanation does not seem entirely satisfactory, since no gum was formed in the phloem region, the area that was discolored. On the other hand, the gum was 
found in the woody portion of the petioles and twigs. 'The gum in the twigs extended for several inches below the portion bearing the injured leaves, considerably farther down in the wood than the discoloration extended in the phloem of the bark. The gum began to form in that portion of the wood most subject to desiccation, namely, that portion of it which adjoins the pith. It then became progressively more evident from the pith outward toward the cambium as conditions became more aggravated.

The point of origin and the successive stages of gum formation in these twigs appeared to be comparable to the method of gum formation in internal decline (endoxerosis) of lemons (Bartholomew, 1928). If this be true it would then seem that excessive desiccation, during and after the death of the leaves, may have been the principal factor which caused the gum to form in the twigs. In the case of the wind-injured twigs, as in the internal-decline twigs, the gum seems to have been formed principally from the starch stored in the cells in the neighborhood of the water-conducting vessels. However, the cell walls and middle lamellas were affected to a certain extent, but not sufficiently to cause them to lose their identity. In the early stages the gum was found in relatively few of the vessels, but in the later stages a large proportion of them were completely clogged.

The availability of water needed by the leaves, their water content, and their ability to conserve their water, appear to be the more important factors governing the extent to which they may be injured by desiccating winds, yet it seems that other important factors must be concerned. The sugar content, accumulation of soluble and insoluble solids, abnormal acceleration of oxidizing enzymes, leaf temperature as influenced by transpiration, viscosity of the sap, etc., may be influencing factors, but from the data at hand the definite part played by each cannot be stated. However, sufficient data are available to show that the factors which permit or prevent the injury of orange foliage by desiccating winds are varied and complicated.

\section{PREVENTIVE AND REMEDIAL MEASURES}

Wind injury is caused by meteorological factors which operate discontinuously at rather long intervals. Their effects are essentially disruptive, i.e., they break the course of processes whose maintained equilibrium is necessary for the economy of the tree. The problem is rather different from that presented by a continuously detrimental factor, e.g., a toxic soil component which continually impairs some essential physiological process. The discontinuous action of the wind 
makes it possible for the trees to make a certain amount of recovery in the intervals between storms and to present a certain amount of resistance to the desiccation produced by the next wind.

This fact simplifies to a certain extent the problem of the orange grower who tries to protect his trees from wind injury. There are about 10 months in which to prepare for wind storms in the remaining 2 months.

Experiments have been carried out to test the efficacy of certain treatments in reducing wind injury.

Spray Treatments.-In 1924 two plots of 8 trees each were sprayed with materials designed to prevent injury from northers. Trenches were dug, and it was found that the soil which had recently been irrigated had a good moisture content except in areas about 15 feet square around each tree in which no furrows were made because of low hanging branches. One plot received whitewash made by slaking 25 pounds of lime in 100 gallons of water and adding 1 pound of casein. The other plot of trees received an emulsion of Volck heavy spray oil (a commercial product used for controlling seale insects) made by mixing 10 gallons of 'prepared' oil with 90 gallons of water.

The white coating on the leaves was intended to reflect part of the heat as well as to impede the loss of water from leaves and twigs. The oil was intended to retard the losses of water from the leaves. The trees were sprayed on September 16, and the first norther occurred November 22 to 24 . On November 29 there were fewer scorched leaves on the trees and fewer dried leaves on the ground where the trees had been sprayed with heavy oil than could be seen under unsprayed trees. The leaves were still covered with a greasy film of oil 75 days after it had been applied.' The application of whitewash had not, however, had any effect in preventing windburn or scorch. Orange trees were also sprayed with oil in 1925. It gave a small amount of protection against the harmful action of winds. Professor H. J. Quayle of this Experiment Station reports that he has observed that it is necessary to apply an oil spray 3 or 4 weeks before a windstorm if the trees are to get maximum protection.

The application of an oil spray may have a deterimental effect if a norther comes within a few days. An oil spray applied to Mr. Hollis Showalter's orange trees 2 days before the severe norther of December 3,1927 , produced great injury. He reported that the skin of the fruit was 'scalded' and that the small branches turned black. The trees had a light crop the next year.

Mr. W. H. Volck has kindly sent us the following memorandum on the problem: 
The occurrence of a Santa Ana windstorm immediately following an application of oil spray often results in an increase of leaf drop and foliage burn. This condition can usually be avoided by carefully timing the application according to local weather conditions. Maximum protection from wind injury has been obtained where the spray was applied from 6 to 8 weeks previous to the season of heavy windstorms.

The initial protection from the use of oil sprays covers a period of 2 or 3 months. After the first 2 or 3 months the protection period, extending as long as 1 year, is partially due to the nearly perfect red-spider control. While we concede that red-spider control is one of the factors involved in the prevention of leaf burn we do not consider it the primary cause.

There is a marked difference between the protection from wind injury obtained from heary, medium, and light oils. The best wind protection has been obtained from the use of medium and heavy oils at dosages sufficient to control seale by the single or combination treatment.

In each locality examined there were cases in which oil sprays had apparently given some protection and other cases in which their application had been followed by serious injury to the trees. With all possible allowance for beneficial effects of oil sprays no instances have been found in which the decrease in wind injury compensated for the labor and expense of spraying. On the contrary, if trees have been seriously weakened, as by infestation with red spider, the oil spray may produce serious defoliation instead of giving the anticipated protection.

Overhead Irrigation.-A few groves equipped with overhead irrigation appliances are located in the wind-exposed area. 'Theoretically there should be some protection from the application of water during a norther, but no satisfactory trial has yet been made. Apparently, some defect, either in management or in mechanical detail, has prevented the application of water at the critical time. The general use of overhead irrigation at the time of a storm would not be feasible because the water supply would be inadequate to supply every grove simultaneously except where the owners had large storage capacity or individual pumping plants.

A small experiment on overhead irrigation was started in September, 1925, on a block of 60 Valencia orange trees on Ramona gravelly loam soil near Villa Park. The system for overhead irrigation was generously furnished and installed by the Hadden Automatic Sprinkler Company.

After using this system 3 months a great improvement in soil condition, due mainly to the disappearance of plow sole and better penetration of water, was noted. The part of the grove which was irrigated by furrows had a very hard plow sole and there the trees were much more severely injured by windburn than in the part irrigated by overhead sprinklers. 
In the following year the owner used better methods of applying the water in furrows and obtained a better distribution, although more water was used. The section irrigated by furrows received 22.2 acre inches for the season, and that irrigated by the overhead sprinklers 16.1 inches. On September 20, 1926, there was no appreciable difference in the condition of the trees. There were no bad storms that year, consequently no data on windburn were obtained.

Soil Moisture Control. ${ }^{8}$-Extensive field observations and soil examinations have conclusively shown that soil-management practices, with their resultant effects on tree growth, influence the extent of injury caused by the dry desert winds that occur during the fall months. Irrigation practice, soil fertilization, and cultivation affect the resistance or susceptibility of the tree to wind injury.

Generally speaking, the orchard that has received ample water during the growing season and prior to the wind period will suffer the least injury, other factors being equal. Ample water means enough moisture to meet the requirements of the tree through the season, yet allowing a reasonable fluctuation of moisture in the root zone so as to provide the optimum air and temperature conditions that encourage maximum root activity. It is this healthy root activity that enables the tree to take up larger amounts of water during the periods of stress, and thus better meet the excessive demands of the tree for moisture. A strong, vigorous root system cannot be developed in a short space of time. It is the result of good soil-management practices over several seasons. The presence of ample moisture just prior to and during a wind storm is not necessarily insurance against damaging desiccation. If the root system has had good environmental conditions, which include fluctuating moisture, soil air, good bacterial activity, and available plant food, then the tree will suffer the least amount of injury; but if excessive irrigation has been the usual practice, particularly too early in the spring, the root system has been weakened; then the soil moisture present during the wind period would have less opportunity to help the trees, because of the lessened absorptive power of the roots.

The length of furrow or water run is an important consideration in the economical and efficient distribution of irrigation water. Coupled with this, is the pattern of spreading, e.g., the basin system on sandy soils or the furrow method on heavy soils. Each soil type presents a different need and it behooves the grower to investigate and study his

8 The sections on "Soil Moisture Control," "Modified Cultivation," and "Fertilization," were prepared by Mr. H. E. Wahlberg, Specialist in Agricultural Extension. 
particular soil type and adopt a system of distribution that will approach most nearly the ideal of uniform penetration and spread.

There have been many demonstrations in local orchards, not protected by windbreaks, of uneven and spotted windburning and defoliation that are at once traceable to unequal and unsatisfactory moisture penetration. The trees at one end of the orchard may be much more severely burned than those at the other end. Dozens of trenches dug in these orchards to investigate and compare root systems revealed a considerable variation in the extent and condition of the roots. Almost invariably the greater defoliation and desiccation is associated with the weaker root systems, other factors being equal. It has become apparent, therefore, from the extensive field observations made during the past 10 years, that intelligent irrigation practice or moisture control in the orchard throughout the entire season is essential in building up maximum tree resistance to wind injury.

Modified Cultivation.-The relation of good, vigorous root development to tree growth is reflected in the manner of orchard cultivation. Heavy root cutting obviously reduces the moisture-absorbing area of the tree and also materially impairs assimilation of plant-food elements. The usual commercial practice of deep subsoiling is generally disappointing in its final effect on citrus trees, especially during a period of dry winds. Many examples of unusual wind damage directly attributable to this cause have come to our attention.

If subsoiling must be resorted to as an emergency measure it should be done on a conservative basis. Going down the middle once in one direction for any given year has been found to be the least harmful. The most effective direction is generally at right angles to the direction of water flow.

The usual purpose of subsoiling is to break up the plow sole which has slowly developed during the life of the orchard. In most cases the plow sole, when actually present (very often the condition is exagerated in the growers' mind), is caused by premature cultivation, that is, working the soil when it is yet too wet to stir. The surface may seem sufficiently dry, but just underneath the soil mass is sticky and wet. When worked in this condition it will pack and assume a plastic consistency that eventually becomes more or less impervious to water.

If subsoiling is practiced to overcome the plow sole it is at best only a temporary relief. Well-timed cultivation and judicious water application will do more to relieve a congested soil condition and give lasting permeability than will severe subsoiling, which invariably involves injurious root pruning to the detriment of the tree.

Deep cultivation also inhibits the normal growth and development of the fibrous roots in the upper areas. To the extent that the fine 
feeder roots and their root hairs are destroyed or disturbed, by so much will the eapacity of the tree to comteract the damaging effects of the wind storms be decreased.

Excessive root disturbance can be avoided by a conservative program of cultivation. In fact, scores of operators of large and small orchard plantings have found that nothing is gained by excessive cultivation and have reduced their cultivation operations and costs as much as 50 per cent.

Fertilization.-It is obvious that a well-fed tree will thrive better under unfavorable wind conditions than a poorly fed one, provided the other phases of orchard management are identical. Organic fertilizer material is of particular advantage to citrus trees in this connection. Not only is the development of citrus roots stimulated by the presence of organic matter in the soil, so that they have greater moisture-absorbing power, but also the moisture-holding eapacity of the soil in the root zone is increased. The regular application of animal manures, legume straws, and the growing of good green manure crops, properly managed, will materially improve the organic content of the soil.

Nitrogen fertilizers, in addition to the bulky organic materials mentioned above, will furnish the balance of the plant food requirements of the normal tree. If nitrogen and organic matter are applied in the proper amount and at the proper time, the feeder roots will multiply and flourish under good irrigation and cultivation practices. The best fertilizer program can be largely defeated, however, by excessive irrigation in the spring and improper cultivation. It is desirable, therefore, that a well-balanced program of orchard management be exercised so that the greatest efficiency may be obtained from the labor and materials involved. And this, in the end, is measured by the greater production of high-quality fruit, which spells maximum returns per acre.

The suggestions presented above, relative to ideal soil and irrigation management, do not offer complete protection from wind damage. They do, however, outline the principal factors that influence the susceptibility or resistance of the citrus tree to the desiccating process accompanying the desert winds. In desiceating winds of high velocity, even the best-managed orchards may suffer considerable damage if not protected by a good windbreak. Protection is an economic necessity in citrus areas that are in the direct path of these annual desert winds (northers). Only by lessening the velocity of the wind, and thus cutting down the volume of dry air passing through the trees, can the injury be reduced to a minimum. 
Windbreaks for Protecting Citrus Orchards. ${ }^{3}$ - Windbreaks of adequate height and density and properly spaced across the direction of prevailing winds, exert a very important influence in many of the citrus districts of California. In some of these sections it is impossible to produce a large proportion of high-quality fruit over a series of years without the protection afforded by well-grown belts of trees. Lacking such protection, orchards are seriously damaged periodically by winds of high velocity and low humidity which not only cause scarring and dropping of fruit, but also the dropping of such a large proportion of foliage and the killing-back of so many terminal shoots that the vitality of the trees is impaired for a long period.

The economic effect of good windbreaks has been repeatedly shown in studies extending over a series of years in important citrus districts. Figures compiled by Wahlberg for one district having inadequate protection, show average shipments from the packing house of 567 cars of fruit per annum for 4 years when serious winds did not occur, but during 4 windy years, the same packing house shipped an average of only 323 cars per annum. In one year of particularly severe wind, groves protected by wind breaks produced 74 per cent of fruit in the upper two grades while unprotected groves vielded only 54 per cent in these grades. Wahlberg also reports the beneficial effects of windbreaks shown by observations in two comparable orange groves after the windstorm of December 3, 1927. One of the groves was protected by a windbreak but the other was not. The average number of fruits blown from the trees in the protected grove was 15 , and from trees in the unprotected grove 278.

The money value of good windbreak protection is well shown by figures furnished by Mr. J. R. Lundemo on the production of two 5 -acre blocks of oranges in 1928 after the severe windstorm of December, 1927, when the velocity of the wind in the open was in excess of 45 miles an hour. In the zone of complete windbreak protection it never exceeded 15 miles an hour, but was greater than this in the 5 acres recorded as having only partial protection. The area of complete protection yielded 84 per cent in the upper two grades as against 66.4 per cent for the partially protected area, the total yield of oranges was 24 per cent higher in the protected zone, and the value of the fruit per tree was $\$ 6.33$ in the first case as against $\$ 3.39$ in the second. Anemometer and production records show that the zone of complete protection extends for a distance of five to six times the height of the windbreak.

9 This section was prepared by Woodbridge Metcalf, Associate Professor of Forestry and Specialist in Agricultural Extension. 
The ideal windbreak tree for any locality is one that makes rapid and vigorous growth to a maximum height of from 65 to 100 feet, maintains foliage of good density, and has sufficient strength in stem and branches to resist breakage by heavy winds and a root system which gives minimum interference with the orchard trees. The tree selected should be reasonably free from attack by disease or insects. Some of these requirements can be modified by proper management, but it is axiomatic that any species which grows rapidly to large size must have a root system in proportion.

In order to approach as closely as possible to the ideal of complete windbreak protection in any given locality, the following elements of windbreak management should be given careful consideration:

1. Choose a species which most nearly meets the requirements of the locality.

2. Make the distance between windbreak rows such that the trees will be able to exert the maximum protective effect when mature. The standard distance is 330 feet in some sections and should rarely exceed 660 feet.

3. Give good soil preparation before planting the trees and if possible start the windbreak a year before the orchard is planted.

4. The spacing distance of trees in the row depends somewhat on the species used, but is generally between 6 and 10 feet. For rows on the exposed, windward side it is often desirable to plant a double row of trees.

5. Use well-grown, sturdy planting stock which has proper balance between top and root, and which is small enough so that the root system has not become cramped or the tree stunted in the nursery. The trees"should rarely be more than 12 inches in height and, if planted from the ordinary flats, a size of 6 to 8 inches is preferable.

6. If the site is deficient in soil fertility it is often desirable to trench along the windbreak rows during preparation of the site and to put in a layer of well-rotted (never green) manure at a depth of about 18 inches in order to stimulate rapid development of trees during the first year. This will usually be necessary only on sterile, sandy soils.

7. Plan to give good cultivation and adequate irrigation to the windbreak during the first and succeeding years. Trees which are neglected often become stunted beyond recovery.

8. Give the windbreak plenty of room to develop without interfering with the orchard trees or cultural operations. The nearest row of orchard trees should usually be at least 18 to 20 feet from the windbreak. 
9. Keep the root system of the windbreak trees within control by starting subsoil root pruning when the trees are 4 to 5 years old and giving adequate applications of fertilizer along the windbreak row. This is particularly important in the case of eucalyptus and tamarisk; less so with cypress or other conifers.

10. Watch earefully for ontbreaks of insects or disease among the windbreak trees and take remedial measures at once. It is rarely advisable to interplant eucalyptus with other trees, because the latter will usually have poor vitality and become subject to enemies.

The important windbreak trees are as follows:

Blue gum (Eucalyptus globulus). This is the best tree for general use, because of its rapid growth and large size (fig. 18). It thrives under a wide variety of conditions, but is not suitable where drought and heat are extreme, as in the Imperial Valley. It is often objected to because of its wide-spreading root system, but this ean be satisfactorily controlled as indicated above. Good low protection can be maintained by planting two rows of trees and cutting one when the lower foliage has thinned out. Sprouts from the cut stumps will fill in nicely (fig. 18). The use of small planting stock is very important to insure a well-developed root system.

Gray gum (Eucalyptus tereticornis) and desert gum (E. rudis) are not to be recommended in sections where blue gum will thrive, for they grow more slowly and have thinner foliage. Both species suceed reasonably well in the Imperial Valley and will have some utility there.

Monterey cypress (Cupressus macrocarpa) does not reach as great ultimate height as blue gum, but is probably the best tree to use in citrus districts near the coast. It has a relatively small root system which can easily be kept within bounds and which does not interfere unduly with the orchard trees. It has several insect enemies that attack it when it is growing under abnormal conditions or in competition with eucalyptus. It cannot be recommended for planting in the interior valleys or for under-planting. Constant watch should be kept for attacks by bark beetles, the cypress bark scale, and a new disease caused by Coryneum sp., which has recently killed a large number of trees in the vicinity of Palo Alto.

Arizona cypress (Cupressus arizonica) is very similar to Monterey cypress, but is better suited to inland interior conditions because it is less apt to be injured by drought and heat. Its use is still in the experimental stage; no very old plantings are in existence. Cypress bark beetle will attack this tree and may prove to be serious. It has done well thus far in the Antelope Valley. 
Tamarisk or desert athel (Tamarix articulata) has been widely heralded as a tree which does not have a wide-spreading root system and is therefore preferable to eucalyptus. This is unfortunately not the case; the roots have been found to be about as extensive and as

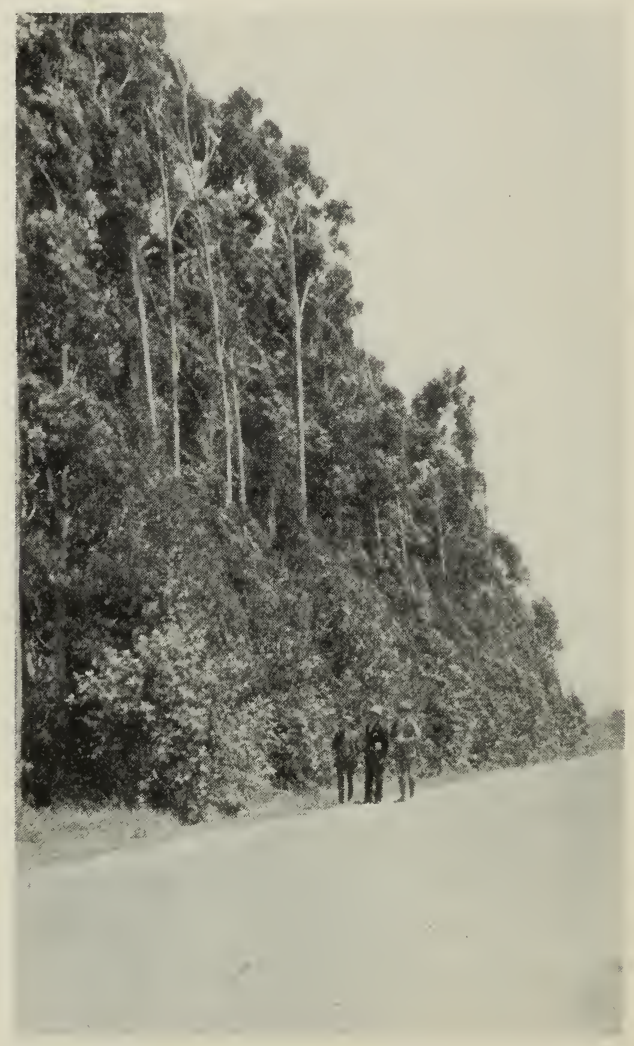

Fig. 18.-A fine windbreak consisting of a double row of Eucalyptus globulus. Cutting the outside row of trees has resulted in a dense growth of sprouts which fill the gaps and give protection near the ground. (Photo by Metcalf.)

voracious for soil fertility as the eucalyptus, and the tree is much shorter, needs constant side trimming to keep it in bounds, and breaks badly in very heavy winds. It is very useful in the Imperial Valley and adjacent territory where better trees do not thrive and may have limited utility in other districts. It has only about half the ultimate height of eucalyptus without the manifest advantages of the latter, so that most plantings of tamarisk are being removed in favor of blue gum where that tree will thrive. 


\section{GENERAL SUMMARY}

1. Extensive damage to citrus trees exposed to desiceating winds is due to defoliation, death of twigs, and loss of fruit. In addition to the losses incurred by dropping many fruits, the growth of those remaining is so restricted that they are undersized at maturity.

2. Citrus trees suffer from excessive transpiration during the windstorms, as well as from the mechanical force of the wind. The defoliation of orange and some other citrus trees is due principally to windburn and scorch, but the defoliation of lemon trees principally to the mechanical force of the wind. Orange trees are often unsymmetrical in form as a result of the death of young shoots year after year on the windward side of the tree.

3 . Trees with a healthy root system growing in a soil whose water content approaches the optimum are best able to meet the demands for water incident to the excessive transpiration rate. Trees whose vitality has been lowered by any cause, such as infestation with insects or fungus diseases, are usually more severely injured by the desiccating winds.

4. The desiccating winds, designated northers, blow from the inland deserts to the coastal plain under certain conditions of barometric pressure. Windburn and scorch of citrus leaves are produced when low humidity, high temperature, and high wind velocity are concurrent. In the Imperial Valley the injurious winds blow from the west during the spring months.

5 . The water content of orange leaves when young is greater than at maturity; however, the young leaves transpire at a slower rate than mature leaves. A large proportion of the transpirational water escapes through the upper, cutinized epidermis which contains no stomata.

6 . The total content of soluble solids of mature leaves is much greater than that of young leaves; likewise the viscosity of the sap of the former is much greater than that of the latter. The content of total solids may materially increase during a period of desiccating wind and then shortly afterward diminish.

7. The sugar content of young leaves is considerably greater than that of mature ones.

8. Evidence is presented which indicates that the death of the twigs and smaller limbs is caused largely by effects produced by the scorched leaves which remain attached to them, rather than by the direct effect of the wind. The phloem of these stems turns brown or black, the water-conducting vessels become partially or wholly clogged 
with gum, and the stem finally dies, while those from which the leaves are detached during the wind storm, or shortly after, usually remain alive.

9. The results of studies on the relation of windbreaks, oil spray, irrigation, cultivation, fertilizer applications, and other factors to the effects of injurious winds are discussed. The minimum damage from the winds has been found in groves where rational practices of tillage and fertilizer application have been followed in conjunction with the development of suitable windbreaks.

\section{LITERATURE CITED}

Anonymous.

1920. A hot "hurricane" ; the levanto of the Canaries. Monthly Weather Rev. $48: 40$.

AskinazY, W.

1928. The "sukhovey" (hot winds) of the plains of southeastern Europe [translated title] Izv. Nauch. Melior. Inst. 17:69-114. Reviewed in Exp. Station Rec. 60:418. 1929.

BARTHOLOMEW, E. T.

1926. Internal decline of lemons. III. Water deficit in lemon fruits caused by excessive leaf evaporation. Amer. Jour. Bot. 13:102-117.

1928. Internal decline (endoxerosis) of lemons. VI. Gum formation in the lemon fruit and its twig. Amer. Jour. Bot. 15:548-563.

BERNBERK.

1920. Die Wasserversorgung der Pflanzen im Winde. Naturwiss. Zeitschr. Forst. u. Landw. 18:121-141.

BLACKMAN, F. F.

1909. Vegetation and frost. New Phytologist 8:354-363.

BLAIR, T. A.

1909. Northers of the Sacramento Valley. Monthly Weather Rev. 37:132.

Boeuf, F. and P. GENET.

1906. Le dessèchement des orangers à la suite des sirrocos d'automne. Revue Horticole Tunisienne 5:20-27, 52-58.

Cameron, Sidney H.

1927. California Agr. Exp. Sta. Rept. 1926-27:91-92.

Chalot, C., and R. Deslandes.

1914. Culture du eitronnier a la Dominique, 68 p. A. Challamel, Paris.

CorT, J. E., and R. W. HodGson.

1919. An investigation of the shedding of young fruits of the Washington Navel orange. Univ. California Publ. Agr. Sci. 3:283-368.

FAWCETT, H. S., and H. A. LeE.

1926. Citrus diseases and their control. 582 pp. 205 figs. MeGraw-Hill, New York City.

GEORGII, W.

1920. Siroceo observations in the southwestern part of Palestine. Monthly Weather Rev. 48:40. 
HaAs, A. R. C., and H. S. Reed.

1927. Relation of desiccating winds to fluctuation in ash content of citrus leaves and phenomenon of mottle-leaf. Bot. Gaz. 83:161-172.

Hodgson, R. W.

1917. Some abnormal water relations in citrus trees of the arid southwest and their possible signifieance. Univ. California Publ. Agr. Sci. 3:37-54.

Kellex, W. P., and A. B. Cummins.

1920. Composition of normal and modified citrus leaves. Jour. Agr. Res. 20:161-191.

Knight, H. G., J. C. Chamberdain, and C. D. Samuei.s.

1929. On some limiting factors in the use of saturated petroleum oils as insecticides. Plant Physiol. 4:299-321.

KoKeTSU, RüCHIRo.

1928. Variation of the water content of leaves as related to the wilting of plants. Jour. Dept. Agric. Kyushu Imperial Univ. 2:94-116.

MASON, T. G.

1923. Ligneous zonation and die-back in the lime (Citrus medica var. acida) in the West Indies. Proc. Roy. Dublin Soc. N. S. $17: 255-262$.

McAdie, A. G.

1912. Climatological data for December, 1912 [Califoruia]. Monthly Weather Rev. 40:1881.

REED, H. S.

1920. Injurious effects of the windstorm of November 20, 1919. California Citrograph 5:178.

SANders, Ellen Mary.

1920. The elimate of Japan and Formosa. Monthly Weather Rev. 48:404-408.

Shreve, Forest.

1913. The transpiration behavior of rain-forest plants. Ann. Rept. Dept. Bot. Res., Carnegie Inst. Wash., Yearbook 12:74-76.

SPOEHR, H. A.

1919. The earbohydrate economy of the Cacti. Carnegie Inst. Wash. Publ. 287:1-79.

SUMMERs, F.

1923. The physiology of leaf seoreh. Jour. Bath and Western and Southern Counties Soc. 17:123-132.

VAILE, R. S.

1924. A survey of orehard practices in the eitrus industry of southern California. California Agr. Exp. Sta. Bul. 374:1-40.

WAYNICK, D. D.

1927. Growth rates of Valencia oranges. California Citrograph 12:150, 164.

1928. Factors concerned in the growth of Valencia orange. California Citrograph 13:200.

YounG, F. D.

1926. Desert winds and windbreak protection. California Citrograph 11:455-484. 

BULLETINS

No.

253. Irrigation and Soll Conditions in the Sierra Nevada Foothills, California.

263. Size Grades for Ripe Olives.

277. Sudan Grass.

279. Irrigation of Rice in California.

283. The Olive Insects of California.

304. A Study of the Effects of Freezes on Citrus in California.

310. Plum Pollination.

313. Pruning Young Deciduous Fruit Trees.

331. Phylloxera-resistant stocks.

335. Cocoanut Meal as a Feed for Dairy Cows and Other Livestock.

343. Cheese Pests and Their Control.

344. Cold Storage as an Aid to the Market ing of Plums, a Progress Report.

346. Almond Pollination.

347. The Control of Red Spiders in Decid. uous Orchards.

348. Pruning Young Olive Trees.

349. A Study of Sidedraft and Tractor Hitches.

353. Bovine Infectious Abortion, and Associated Diseases of Cattle and New born Calves.

354. Results of Rice Experiments in 1922.

357. A Self-Mixing Dusting Machine for Applying Dry Insecticides and Fungicides.

361. Preliminary Yield Tables for Second Growth Redwood.

362. Dust and the Tractor Engine.

363. The Pruning of Citrus Trees in California.

364. Fungicidal Dusts for the Control of Bunt.

366. Turkish Tobacco Culture, Curing, and Marketing.

367. Methods of Harvesting and Irrigation in Relation to Moldy Walnuts.

368. Bacterial Decomposition of Olives During Pickling.

369. Comparison of Woods for Butter Boxes.

370. Factors Influencing the Development of Internal Browning of the Yellow Newtown Apple.

371. The Relative Cost of Yarding Small and Large Timber.

373. Pear Pollination.

374. A Survey of Orchard Practices in the Citrus Industry of Southern California.

380. Growth of Eucalyptus in California Plantations.

385. Pollination of the Sweet Cherry.

386. Pruning Bearing Deciduous Fruit Trees.

388. The Principles and Practice of Sun Drying Fruit

389. Berseem or Egyptian Clover.

390. Harvesting and Packing Grapes in California.

391. Machines for Coating Seed Wheat with Copper Carbonate Dust.

392. Fruit Juice Concentrates.

393. Crop Sequences at Davis.

394. I. Cereal Hay Production in California. II. Feeding Trials with Cereal Hays.

395. Bark Diseases of Citrus Trees in California.

396. The Mat Bean, Phaseolus Aconitifolius.

397. Manufacture of Roquefort Type Cheese from Goat's Milk.

400. The Utilization of Surplus Plums.

405. Citrus Culture in Central California.

406. Stationary Spray Plants in California.

407. Yield. Stand, and Volume Tables for White Fir in the California Pine Region.
No.

408. Alternaria Rot of Lemons.

409. The Digestibility of Certain Fruit By F'roducts as Determined for Ruminants. Part I. Dried Orange Pulp and Raisin Pulp.

410. Factors Influencing the Quality of Fresh Asparagus After it is Harvested.

412. A Study of the Relative Value of Certain Root Crops and Salmon Oil as Sources of Vitamin A for Poultry.

414. Planting and Thinning Distances for Deciduous Fruit Trees.

415. The Tractor on California Farms.

416. Culture of the Oriental Persimmon in California.

418. A Study of Various Rations for Finishing Range Calves as Baby Beeves.

419. Economic Aspects of the Cantaloupe Industry.

420. Rice and Rice By-Products as Feeds for Fattening Swine.

421. Beef Cattle Feeding Trials, 1921-24.

423. Apricots (Series on California Crops and Prices).

425. Apple Growing in California.

426. Apple Pollination Studies in California.

427. The Value of Orange Pulp for Milk Production.

428. The Relation of Maturity of California Plums to Shipping and Dessert Quality.

430. Range Grasses in California.

431. Raisin By-Products and Bean Screenings as Feeds for Fattening Lambs.

432. Some Economic Problems Involved in the Pooling of Fruit.

433. Power Requirements of Electrically Driven Dairy Manufacturing Equipment.

434. Investigations on the Use of Fruits in Ice Cream and Ices.

435. The Problem of Securing Closer Relationship between Agricultural Development and Irrigation Construction.

436. I. The Kadota Fig. II. The Kadota Fig Products.

438. Grafting Affinities with Special Refer ence to Plums.

439. The Digestibility of Certain Fruit By Products as Determined for Ruminants. II. Dried Pineapple Pulp, Dried Lemon Pulp, and Dried Olive Pulp.

440. The Feeding Value of Raisins and Dairy By-Products for Growing and Fattening Swine.

444. Series on California Crops and Prices: Beans.

445. Economic Aspects of the Apple Industry.

446. The Asparagus Industry in California.

447. A Method of Determining the Clean Weights of Individual Fleeces of Wool.

448. Farmers' Purchase Agreement for Deep Well Pumps.

449. Economic Aspects of the Watermelon Industry.

450. Irrigation Investigations with Field Crops at Davis, and at Delhi, California, 1909-1925.

451. Studies Preliminary to the Establish ment of a Series of Fertilizer Trials in a Bearing Citrus Grove.

452. Economic Aspects of the Pear Industry

453. Series on California Crops and Prices: Almonds.

454. Rice Experiments in Sacramento Valley, 1922-1927. 
No.

455. Reclamation of the Fresno Type of Black-Alkali Soil.

456. Yield. Stand and Volume Tables for Red Fir in California.

458. Factors Influencing Percentage Calf Crop in Range Herds.

459. Economic Aspects of the Fresh Plum Industrv.

460. Series on California Crops and Prices: Lemons.

461. Series on California Crops and Prices: Economic Aspects of the Beef Cattle Industry.

462. Prune Supply and Price Situation.

464. Drainage in the Sacramento Valley Rice Fields.
No.

465. Curly Top Symptoms of the Sugar Beet.

466. The Continuous Can Washer for Dairy Plants.

467. Oat Varieties in California.

468. Sterilization of Dairy Utensils with Humidified Hot Air.

469. The Solar Heater.

470. Maturit" Standards for Harvesting Bartlett Pears for Eastern Shipment.

471. The Use of Sulfur Dioxide in Shipping Grapes.

474. Factors Affecting the Cost of Tractor Logging in the California Pine Region.

475. Walnut Supply and Price Situation.

\section{CIRCULARS}

No.

115. Grafting Vinifera Vineyards.

117. The Selection and Cost of a Small Pumping Plant.

127. House Fumigation.

129. The Control of Citrus Insects.

164. Small Fruit Culture in California.

166. The County Farm Bureau.

178. The Packing of Apples in California.

203. Peat as a Manure Substitute.

212. Salvaging Rain-Damaged Prunes.

230. Testing Milk, Cream, and Skim Milk for Butterfat

232. Harvesting and Handling California Cherries for Eastern Shipment.

239. Harvesting and Handling Apricots and Plums for Eastern Shipment.

240. Harvesting and Handling California Pears for Eastern Shipment.

241. Harvesting and Handling California Peaches for Eastern Shipment.

243. Marmalade Juice and Jelly Juice from Citrus Fruits.

244. Central Wire Bracing for Fruit Trees.

245. Vine Pruning Systems.

248. Some Common Errors in Vine Pruning and Their Remedies.

249. Replacing Missing Vines.

250. Measurement of Irrigation Water on the Farm.

253. Vineyard Plans.

255. Leguminous Plants as Organic Fertilizers in California Agriculture.

257. The Small-Seeded Horse Bean (Vicia faba var. minor).

258. Thinning Deciduous Fruits.

259. Pear By-Products.

261. Sewing Grain Sacks.

262. Cabbage Production in California.

263. Tomato Production in California.

265. Plant Disease and Pest Control.

266. Analyzing the Citrus Orchard by Means of Simple Tree Records.
No.

269. An Orchard Brush Burner.

270. A Farm Septic Tank.

276. Home Canning.

277. Head, Cane, and Cordon Pruning of Vines.

278. Olive Pickling in Mediterranean Countries.

279 The Preparation and Refining of Olive Oil in Southern Europe.

282. Prevention of Insect Attack on Stored Grain.

284. The Almond in California.

287. Potato Production in California.

288. Phylloxera Resistant Vineyards.

289. Oak Fungus in Orchard Trees.

290. The Tangier Pea.

292. Alkali Soils

294. Propagation of Deciduous Fruits.

295. Growing Head Lettuce in California.

296. Control of the California Ground Squirrel.

298. Possibilities and Limitations of Cooperative Marketing.

300. Coccidiosis of Chickens.

301. Buckeye Poisoning of the Honey Bee.

302. The Sugar Beet in California.

304. Drainage on the Farm.

305. Liming the Soil.

307. American Foulbrood and Its Control.

308. Cantaloupe Production in California.

309. Fruit Tree and Orchard Judging.

310. The Operation of the Bacteriological Laboratory for Dairy Plants.

311. The Improvement of Quality in Figs.

312. Principles Governing the Choice, Operation and Care of Small Irrigation Pumping Plants.

313. Fruit Juices and Fruit Juice Beverages.

314. Termites and Termite Damage.

315. The Mediterranean and Other Fruiı Flies. 